\title{
Years of Good Life: An illustration of a new well-being indicator using data for Thailand
}

\author{
Thananon Buathong ${ }^{1}$, Anna Dimitrova ${ }^{2, *}$, Paolo Miguel M. Vicerra ${ }^{3}$ \\ and Montakarn Chimmamee ${ }^{4}$
}

\section{Abstract}

While Thailand has achieved high levels of economic growth in recent decades, poverty at the local level has been increasing. Indicators of human development at the national level often mask the differences in well-being across communities. When responding to the need for sustainable development research, the heterogeneity of a population should be emphasised to ensure that no one is left behind. The Years of Good Life (YoGL) is a well-being indicator that demonstrates the similarities and differences between subpopulations in a given sociocultural context over time. The data used in this analysis were collected from Chiang Rai and Kalasin, which are provinces located in regions of Thailand with high poverty rates. Our main results indicate that the remaining years of good life (free from physical and cognitive limitations, out of poverty and satisfied with life) at age 20 among the sample population were 26 years for women and 28 years for men. The results varied depending on the indicators applied in each dimension of YoGL. Our analysis of the YoGL constituents indicated that cognitive functioning was the dimension that decreased the years of good life the most in the main specification. This study demonstrates the applicability of the YoGL methodology in investigating the wellbeing of subpopulations.

Keywords: well-being; Thailand; survey design; data collection

\footnotetext{
${ }^{1}$ Faculty of Sociology and Anthropology, Thammasat University, Thailand

${ }^{2}$ Scripps Institution of Oceanography, University of California, San Diego

${ }^{3}$ College of Population Studies, Chulalongkorn University, Thailand

${ }^{4}$ Social Research Institute, Chulalongkorn University, Thailand

*Correspondence to: Anna Dimitrova, adimitrova@ucsd.edu
} 


\section{Introduction}

Thailand has experienced strong economic growth in recent decades. Indeed, by 2011, Thailand had gained the status of an upper-middle income country (Gil Sander and Burgard 2011). In 2019, the gross domestic product (GDP) of Thailand amounted to US $\$ 543.7$ billion, which made it the second-largest economy in Southeast Asia, and the eighth-largest economy in Asia (World Bank 2019). Despite these positive changes in the national economy, gains in the levels of human development in Thailand have been inconsistent over time and across population subgroups. Moreover, the levels of development in different locations of the country have varied (Yang et al. 2020). In particular, the provinces in the north and northeastern regions are notably poorer than other parts of the country. For example, from 2011 to 2013, Bangkok experienced annual economic growth of 10\%, while the north and north-eastern regions had growth rates below 5\%. In addition, while consumption growth has been increasing in the poorer regions, income growth has remained unchanged (Yang et al. 2020). When assessing growth and development in a given society, GDP offers some information, but it has limitations, as it only measures national aggregates, while failing to account for non-economic determinants of human development (Stiglitz et al. 2010).

Over the past 50 years, a wide range of well-being indices have been introduced to assist policymakers seeking to improve the quality of human life and contribute to the broader discussion of what constitutes sustainable development. These indices include the Better Life Index from the Organization for Economic Co-operation and Development (OECD), the Ecological Footprint (EF), the Global Well-Being Index (GWI), the Happy Planet Index (HPI), the Human Development Index (HDI) and the Sustainable Society Index (SSI), to mention a few (Mclean 2014; Strezov et al. 2017). This wide variety of indices points to differences in the understanding of quality of life based on the country context and/or the agency's objectives (Mclean 2014), and signals the need for a more holistic approach to studying well-being.

Most of these indices look beyond the measurement of GDP, and devote more attention to a broader spectrum of social and ecological issues, including the sustainability of social and natural capital and good governance (i.e., OECD Better Life Index, Social Progress Index, Happy Planet Index). The OECD Better Life Index, for example, integrates multiple dimensions of well-being through an interactive online interface, which allows the user to choose from 11 domains, ranging from current conditions in housing to life satisfaction and work-life balance. Although these indices cover dimensions relevant for human well-being beyond simple economic growth, using them to measure well-being has certain disadvantages. As various commodities and technological regimes can change across places and over time, the nature of the determinants included in human development indices can also change, and may thus become difficult to compare (Dasgupta 2004).

There are also indices that completely ignore economic factors, such as the Happy Planet Index, which combines information on mortality and life satisfaction in different countries with data on their respective ecological footprints. While 
mortality and stated life satisfaction are measures of current well-being, a country's ecological footprint is not directly reflected in its current conditions, but instead measures possible impacts on future well-being. Therefore, this index has a dual function that makes its direct interpretation difficult.

While each of these proposed indices covers various aspects of human wellbeing, there is an increasing recognition that quality of life measures should place more emphasis on the conditions experienced by people at the individual and household levels, rather than on the performance of economic systems at the macro level (Veneri and Edzes 2017). Highly aggregated indicators conceal large inequalities in the distribution of well-being within a society. Utilising individual characteristics aggregated at the subpopulation level can help to overcome the aforementioned limitations of national-level indicators (Mascarenhas et al. 2010). This is particularly important when considering well-being from a sustainability science perspective. Thus, the objective of "leaving no one behind" can be realised by recognising the social gradients in well-being determined by gender and urbanrural residence, among other factors.

In addition, these improved indices should acknowledge the multidimensional nature of human well-being. The academic literature has recognised that no single measure can capture all aspects of human well-being (Chakravarty 2017), and has yet to agree on its most important dimensions. A related point is that different cultures may have different understandings of what constitutes a good life.

Efforts have been made to apply the different aspects of the aforementioned human development indices in the context of Thailand, and thus to move beyond an exclusive focus on economic growth. A study that aimed to describe wellbeing at the local level was conducted in the north-eastern and southern regions of Thailand (McGregor 2008). In the study, several qualitative and quantitative techniques were used to assess the profile of each community, including its quality of life, expenditures, resources, health and well-being regime. However, a major limitation of the study's approach was its lack of applicability to other communities, or even to countries. Another study aimed to formulate indicators of development based on focus group discussions with local community leaders in the north-eastern region of Thailand (Weeranakin and Promphakping 2018). The result was the identification of a set of themes, such as community trust, well-being, security and strength. However, no further attempts were made to achieve universal applicability. In addition, the methods of analysis used in both studies were intrinsically subjective because they involved qualitative assessments made by researchers.

Thus, several issues concerning the use of the existing human development measures have been raised. To gather information about the various aspects that contribute to human well-being, indices must be constructed to ensure that they reflect how the lives of the people in a given society are improving. However, indices that use aggregated indicators to capture a complex reality face limitations and challenges. From a methodological perspective, the weights assigned to indicators in some of these indices are arbitrary (Lorenz et al. 2017). Thus, the values reported for different populations can be difficult to compare. Moreover, when looking at the 
temporal comparability of these indices, it is clear that the selected indicators and how they are computed may change over time, which can cause the values of a given index to be different in each period (Ghislandi et al. 2019).

The preference for using objective or subjective indicators constitutes another rift in the academic literature on well-being (Easterlin 1974; Diener et al. 1999, 2017; Kahneman 1999). While some scholars have pointed out the cultural and other sources of bias in self-reported measures, such as life satisfaction and happiness, proponents of subjective measures have argued that individuals are best equipped to evaluate their own life circumstances (Frey and Stutzer 2002). Moreover, subjective measures can capture aspects of well-being that are important to individuals, but that may not be seen as such by external evaluators. However, the use of objective or subjective measures need not be mutually exclusive (Lutz et al. 2021).

The rest of this paper focuses on a new and improved well-being indicator, Years of Good Life (YoGL), which was recently introduced by researchers at the International Institute for Applied Systems Analysis (Lutz et al. 2018, 2021). This indicator addresses the shortcomings of the existing well-being measures discussed above, as it is based on individual-level data that can be flexibly aggregated at the subpopulation level; it is designed to be comparable over time; and it is based on universally shared values. Another advantage of the YoGL indicator is that unlike more abstract indices, it can be interpreted directly. It also allows researchers to assess objective and subjective dimensions of well-being, without involving arbitrary weights.

The YoGL indicator rests on the notion that while being alive is a prerequisite for having any quality of life, mere survival is not enough. Using a demographic life table approach, the indicator adjusts overall life expectancy by counting only the number of years in which individuals have a positive score in each of the following four dimensions: (1) being physically healthy; (2) being cognitively able; (3) being out of poverty; and (4) being subjectively satisfied with life. Each of the four dimensions is captured by a single indicator. The YoGL project builds on the existing work on "Healthy Life Expectancy" (Salomon et al. 2012), and provides a more holistic representation of well-being over the life span. A detailed discussion of YoGL and its dimensions is available in Lutz et al. (2021).

In this paper, we present a practical example of how YoGL can be calculated in the context of two Thai provinces, Chiang Rai and Kalasin, which are located in the northern and the north-eastern regions, respectively. Previous studies have shown that these two locations have experienced above-average rates of poverty in recent decades (McGregor 2008; Weeranakin and Promphakping 2018; Yang et al. 2020). Given the level of development Thailand has achieved based on nationallevel measures, it is important to understand how progress varies at the subnational level, especially in areas where poverty and other social challenges persist. To this end, data were collected for each of the four YoGL dimensions, and were then applied to a life table by adjusting the age- and sex-specific person-years lived within the population by the share of people who had positive scores in all four dimensions. We also discuss alternative measures for each of the four dimensions 
of well-being, and we present the YoGL results based on a set of preferred indicators.

As was mentioned above, the YoGL indicator has four dimensions that can be subsumed under two main themes: capable longevity and years with positive life satisfaction (Lutz et al. 2021). Capable longevity is measured based on objectively assessable criteria of what constitutes a good life that reflect the three capabilities of basic health, basic material subsistence and cognitive functioning (Desai et al. 1992). These three components are in line with the general approach that was employed in the Human Development Index. However, for the purposes of measuring YoGL, the conceptualisation and operationalisation of these components were refined (Lutz et al. 2021). One of the core dimensions of YoGL is physical health, and, in particular, having no severe activity limitations. Asking a person about his/her difficulties in activities of daily living (ADLs) or testing his/her physical performance limitations, such as getting up from a chair or walking, can provide an objective approximation of the person's overall health (Weber 2016). Cognitive abilities represent another dimension of YoGL that, like health, declines with age. Cognitive abilities can be assessed through standard numeracy and literacy tests. It should be emphasised that a person's cognitive abilities are not the same as his/her educational attainment. Being out of poverty is the third objective dimension of YoGL, which measures the economic aspects of well-being. An absolute measure of poverty is preferred to a relative measure that reflects social inequalities. Household assets can be used as a proxy for material living conditions, particularly in low- and middle-income countries, where individual reporting on income is less reliable (LokDessallien 2000). The final dimension of YoGL is life satisfaction, which is assessed through an individual's perception of his/her own life. Whether the four proposed indicators are adequate to measure human well-being has yet to be determined in a series of simultaneous studies.

The rest of this paper is organised as follows: In Section 2, we describe the survey design and data collection in the context of two Thai provinces. The results of the survey are presented in Section 3, along with a practical example of how YoGL can be calculated. Section 4 concludes.

\section{Data and method}

\subsection{Dataset}

The dataset used for this study came from the project Developing a measure of human well-being and understanding drivers of sustainable livelihoods under global environmental change. This dataset was compiled by the Chulalongkorn University College of Population Studies and the International Institute for Applied Systems Analysis (IIASA). The selection of the provinces was based on the prevalence of poverty and the socio-economic vulnerability of the population. 
The survey was conducted accordingly, and provincially representative data were collected in two locations: Chiang Rai and Kalasin, which are located in the northern and the north-eastern part of Thailand, respectively. The project was approved by the ethics board of Chulalongkorn University (COA No. 160/2561).

\subsection{Sampling}

To identify provincially representative households, we adopted the sampling frame developed for the 2016 national survey called the Population Change and Wellbeing in an Ageing Society (PCWAS) by the College of Population Studies, Chulalongkorn University. Two districts (Amphoe) were selected from the original provinces included in the PCWAS survey: the Muang district was purposefully selected in order to ensure the inclusion of respondents from a highly urbanised area; while the second district was randomly selected. Furthermore, one municipal sub-district and one non-municipal sub-district (Tambon) were chosen within each sampled district (total sub-districts $=4$ ).

One advantage of adopting the sampling frame established by the PCWAS was that household listings and location maps were already available. The household listings provided the total number of households within the sampled sub-districts and a short description of each household. The location maps, which were produced during the household listing process, depicted the locations of the sampled subdistricts and their entire boundaries, as well as of the households within each sampled sub-district. All listings were updated once the project team entered the field, and the sampled households were approached with the help of the community/village leaders.

To allow for a meaningful statistical analysis, our target was to have at least 500 respondents from each province. To cover non-response or absence, we increased the sample by roughly $10 \%$, to 552 . Based on the most recent information from the United Nations' World Urbanization Report (United Nations 2019b), we specified an equal share of respondents from the selected municipal and non-municipal sub-districts (50/50). Since the number of respondents varied depending on the household size, as we explained above, approximately $75 \%$ of households within every sampled sub-district were likely to be approached. At least one or two Thai persons aged 20 years or older who had been living in the sampled household for at least three months were approached with the assistance of community/village leaders, as previously mentioned, and were asked if they were willing to participate in the project. Those individuals who were not Thai, were not willing, or were unable to give consent to participate in the project were excluded from the study. Household re-visits were also possible if the interviews were not completed. Due to the design and the scale of the data collection, there was no calculation of statistical weights, because information was gathered from the target households in the communities. 
Interviews were conducted face-to-face with one or more household members, depending on the number of adults living in the household. In order to obtain information on the economic activities and status of the household (e.g., income and occupation), the survey focused only on the household member(s) aged 20 years and older. The list enumerating the household members was arranged with the head of the household first, then the partner, then the children, and finally the youngest members. The household head was usually a male adult, though if the parents of a male adult were present, they were listed as the head. Thus, under this procedure, the respondents were selected in a specific manner. In households with between one and three adult members, the second person on the list was asked to participate in the interview. In households with four or more adults, the fourth person was also included in the survey. Due to the selection procedure described above, women were more likely to be interviewed (i.e., the second person listed in the household was usually female). Since the resulting sample was not representative of the overall population (women were overrepresented relative to men), in the subsequent analysis, we presented the results separately for men and women. The small sample size was a major limitation of this study, particularly for certain age groups (e.g., ages 20-35).

Figure 1 shows a population pyramid based on the sample of survey participants, in which $68 \%$ were female and $32 \%$ were male. The median age was 53 ; the youngest participant was 18 and the oldest was 100 years old. When we compared this distribution with the figures from the PCWAS, we found that the current sample was similar. Non-response from the selected respondents was low, at below $1 \%$. A total of 999 participants were interviewed.

\section{Figure 1:}

Distribution of total sample by age and gender

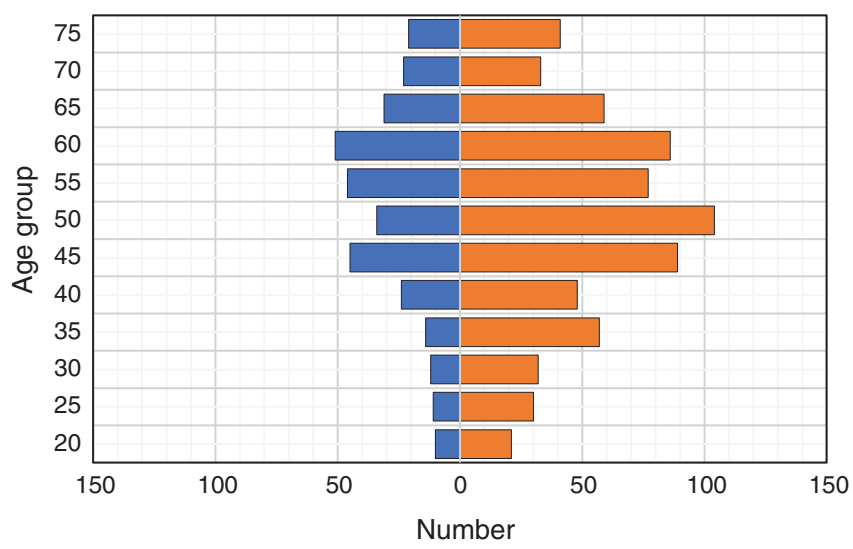

Notes: Median age $=53$, STD. $=14.43$. 


\subsection{Fieldwork and data collection procedures}

About 40 college students from two local universities, Chiang Rai Rajabhat University and Mahasarakam University, were hired as survey interviewers. The recruitment was done through personal connections with local researchers. All of the college students underwent training on the following activities:

\subsubsection{Training session}

All field interviewers were trained thoroughly by the project team on how to explain the project goals. They were also instructed on: (1) how to approach potential respondents; (2) how to ask questions, especially sensitive or complicated ones; (3) how to record answers; (4) what to do in certain situations, for example, if the respondent refuses to take part in the survey; and (5) how to perform consistency checks during the interview or right after the interview is completed. Case-scenario and role-play exercises were carried out during the training sessions to increase the interviewers' familiarity with the questionnaire.

\subsubsection{Field editing}

The editing work was carried out twice during the data collection process. The first round of editing work was done by the interviewers themselves, just after the completion of the interview, to make sure that the entire questionnaire was filled out. The second round of editing work was carried out by the field supervisors to clarify responses; i.e., to assign the respondents' answers to specific categories.

\subsubsection{Daily debrief}

A group debriefing was held at the end of each day in the field. During the meeting, the interviewers were encouraged to reflect on and share their field experiences and impressions, as well as any issues they encountered during the fieldwork. They were also asked for their opinions on how such issues could be resolved. If a specific problem had not yet been resolved, the field supervisor and the interviewers discussed it in depth, and looked for a solution.

\subsubsection{Office editing}

This editing was performed by the project team at the central office (CPS or SRI) after the entire fieldwork had been completed. The editing work included (1) data scrutiny, verification and correction; and (2) the classification of responses (e.g., text or non pre-coded answers). 


\subsection{Measurement}

In this section, we describe in detail the statistical data and procedures we used to measure the Years of Good Life in the context of the two Thai provinces. We propose one main indicator in each of the four YoGL dimensions, and we discuss alternative indicators, which are later used in a sensitivity analysis (Appendix A.2, Table A.1). A notable criterion for the selection of an indicator is that its distribution has to be on the tail ends of the distribution in order to identify individuals in dire conditions (Lutz et al. 2021).

The items were based on standard international surveys, such as the Demographic and Health Survey, to ensure the reliability of the information collected. The translation of the items from English to Thai was carried out by research scientists involved in the project, and crosschecked by the principal investigator. A subsequent back-translation was performed with an equally stringent process to check the validity of the initial translation to the Thai language. The Thai language version of the questionnaire was pre-tested three times to ensure that the wording of the questions was appropriate for the Thai context. Note that when applicable, we also provide the corresponding question number in the Thai version of the questionnaire for reference.

\subsubsection{Physical limitations}

Due to bias in self-reported measures of health (Spitzer and Weber 2019), objective measures should ideally be used to assess the health status of individuals. This can be done through physical tests, such as chair stand and walking speed tests, both of which have been extensively used in surveys on health and ageing (SAGE and SHARE, for example). However, conducting physical tests can be time-consuming, and requires the additional training of interviewers. For the purposes of this project, data on both objective and subjective measures of health were collected.

The ability of each respondent to get into and out of a chair without assistance was assessed objectively by the interviewer. After confirming that they felt safe performing physical tasks, respondents were asked to perform the action of getting into and out of a chair from a sitting position without assistance, and their performance was assessed by the interviewer. In this context, "assistance" refers to the respondents using their arms when performing the test. This chair stand test is commonly used to assess age-related decline in physical functioning and power, since rising from a chair requires both lower limb strength and power, as well as balance and coordination. Figure 2 shows the types of chairs used to perform the chair stand test during the field work.

In addition to the chair stand test, we collected information on the subjective health status of individuals, which is also widely used in the literature. One direct approach is to simply ask the respondents to describe their perceived level of disability as measured by the concept of general activity limitations. In the survey, we used the following question from the Global Activity Limitation 
Figure 2:

Types of chairs used to test physical health in the Thai survey context
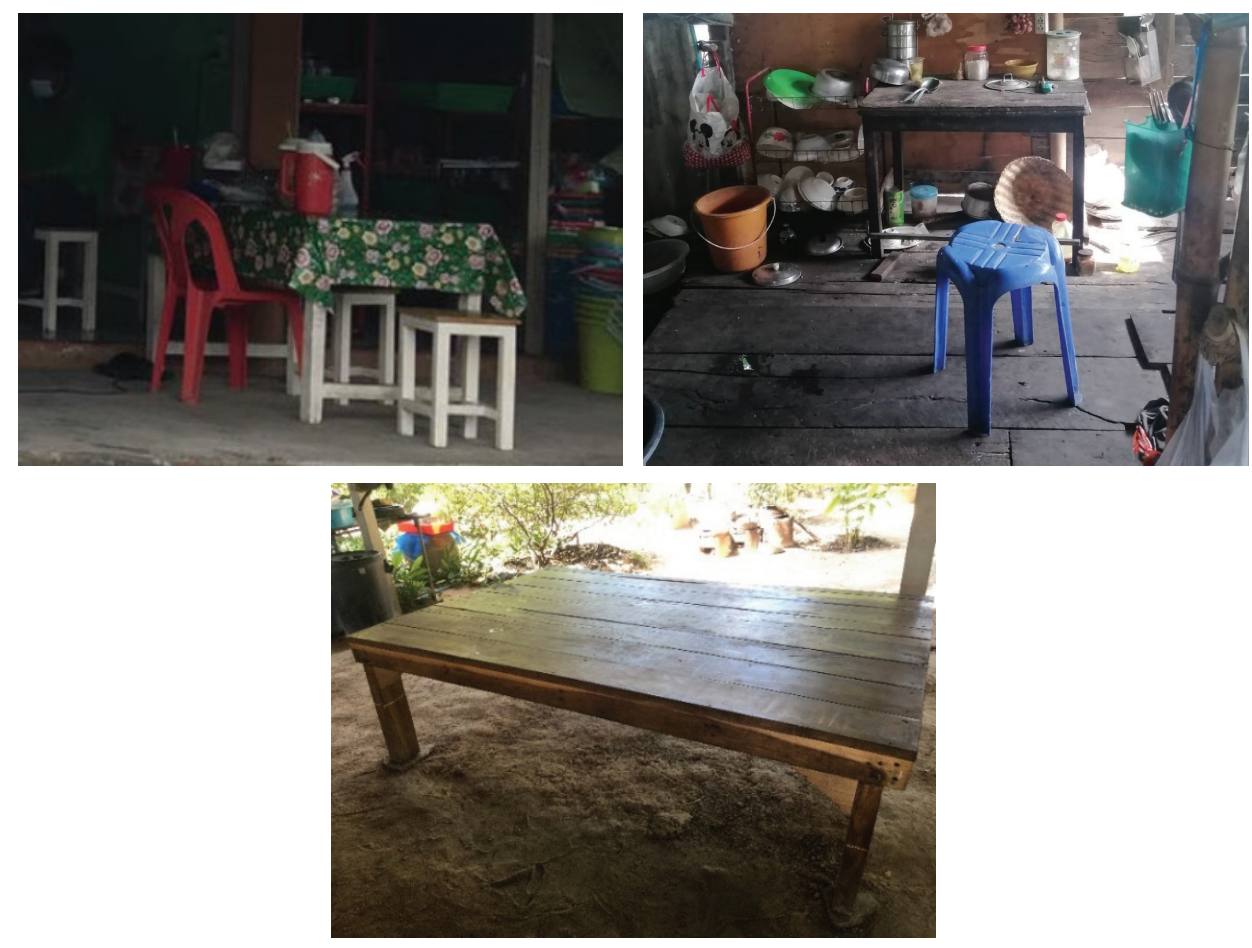

Instrument (GALI): "For at least the past 6 months, to what extent have you been limited because of a health problem in activities people usually do?" (Jagger et al. 2010).

Another approach to measuring disability is to assess the difficulties people have in performing activities of daily living (ADLs). There are six basic ADLs: eating, bathing, getting dressed, toileting, transferring and continence. The six dimensions follow a hierarchical structure. See Section B of the questionnaire in Appendix A.1 for a list of the items used to assess GALI and ADLs in the survey. More comprehensive lists of ADLs are also available. For example, the World Health Organization's Assessment Schedule was developed through an international collaboration in order to assess health and disability status in a way that would be applicable across cultures and in all adult populations. It is a tool that produces standardised disability levels directly linked with the concepts of the International Classification of Functioning, Disability and Health (ICF). It is applicable to a range of diseases, including mental, neurological and addictive disorders (Üstün et al. 2010). 
The extended ADL lists include between 12 and 36 items. The 12 -item version explains $81 \%$ of the variance of the 36 -item version, and it is short, simple and easy to administer (average time of five minutes). Moreover, the 12-item version is applicable in both clinical and general population settings (Üstün et al. 2010). It covers six domains of functioning: cognition, mobility, self-care, getting along, life activities and participation.

While collecting subjective health information is easier, subjective assessments are not considered to be as reliable as objective health measures. We have constructed the YoGL indicator based on both objective and subjective health measures, and compared the differences in the outcomes (see the sensitivity analysis in the results section).

\subsubsection{Cognitive limitations}

The second dimension of the YoGL indicator captures the cognitive functioning of the respondents. Similar to physical health, it should ideally be assessed through objective tests, such as through tests of literacy, numeracy and memory. In the survey, we included three tests of cognitive functioning with different levels of difficulty. We also included a question on self-reported literacy for comparison.

There are many demographic and health surveys around the world that include questions about the participants' literacy, numeracy and/or memory in the context of healthy ageing (e.g., SHARE and SAGE). In addition, a range of instruments have been specifically developed to capture a more holistic picture of the participants' cognitive skills (e.g., Skills Towards Employment and Productivity - STEP) (Pierre et al. 2013). Given the time restrictions of our survey, and given that the scope of the survey was not limited to testing cognitive function, but included other dimensions of well-being as well, we attempted to design a series of questions that, while short, were relatively comprehensive. Specifically, the questions covered the ability to read a simple sentence (C1) (based on DHS), the ability to recognise print vocabulary (C4) (based on PIAAC/STEP), the ability to process a sentence (C5) (PIAAC/STEP) and the ability to correctly identify the day of the week (C6) (based on SHARE) as a proxy for cognitive functioning. By including questions from DHS, SHARE and PIAAC/STEP, we were not only building on existing knowledge; we were ensuring the comparability of the results. The detailed questions are included in Section C of the questionnaire (See Appendix A.1).

\subsubsection{Being out of poverty}

Economic items were also included in the questionnaire in order to capture the respondents' capability to fulfil their basic needs. Since this project was concerned with the severe deprivation of basic needs, it relied on absolute rather than relative measures of poverty. Absolute poverty is traditionally measured in monetary terms, such as the share of the population below a certain level of income or consumption 
expenditure. For example, the World Bank has set the poverty threshold at $\$ 1$ a day (Ferreira et al. 2016). The use of such measures in the context of developing countries has been criticised because collecting reliable data can be difficult, and defining an internationally comparable poverty line can be a challenge (Jolliffe and Prydz 2016). Moreover, income and expenditure data are usually collected at the household level, and disaggregation to the individual level is problematic. More recent measures of poverty go beyond monetary considerations, and thus incorporate multiple indicators of different dimensions of poverty, such as housing, unemployment, nutrition status and access to services, to mention a few (e.g., the Multidimensional Poverty Index and the DHS wealth index).

In light of the above considerations, a set of questions on household living conditions and personal items were selected to capture absolute poverty among the survey participants. Information was collected on the following items:

A. Ownership of basic household items/living conditions:

- Type of toilet facility (G5)

- Main material of outside walls of dwelling (G1)

- Asset ownership: The household owns a refrigerator (G6)

B. Individual items:

- Skipping meals because there is not enough food in the house (D1)

- Limiting variety of foods due to a lack of resources (D3)

The wall type and toilet facility have been used in both the MPI and the DHS as economic indicators, and have been found to strongly correlate with household wealth (OPHI 2009). Ensuring adequate sanitation was also part of the Millennium Development Goals (MDGs), and is currently included in SDG 6 ("Access to safe water and sanitation"). While the living conditions applied to the whole household, this project was particularly interested in assessing individual deprivation, which might not have been the same among household members. Individual dimensions of poverty were captured through questions on food consumption and asset ownership. The questions related to the measurement of poverty are presented in Sections D and $\mathrm{G}$ in the questionnaire (see Appendix A.1).

\subsubsection{Life satisfaction}

The final dimension was concerned with the respondents' satisfaction with life. Considerable attention has been paid to this aspect of subjective well-being (SWB), with several studies on this topic appearing each year (Diener et al. 2017). Life satisfaction is considered a more accurate measure of SWB than happiness, because it requires a respondent to engage in a more reflective review of his/her entire life. By contrast, questions about happiness can yield volatile responses due to the emotional state it can elicit in individuals (Diener et al. 2017). In the current study, we used 
the Satisfaction with Life Scale (SWLS), which consists of five questions that were developed to assess the respondents' satisfaction with their life as a whole (Pavot and Diener 2008). Since its initial development as a brief assessment tool indicating satisfaction with one's life as a whole (Larsen et al. 1985), it has been demonstrated that the SWLS has good psychometric characteristics, and can be used in various contexts and cultures (Pavot and Diener 1993, 2008). While the scale does not assess satisfaction with individual life domains, such as health or finances, it allows the respondents to integrate and weight these domains in whatever way they choose. The following items comprise the SWLS, each of which can be ranked from one (lowest score) to five (highest score) by the respondent:

- In most ways my life is close to my ideal (F1);

- The conditions of my life are excellent (F2);

- I am satisfied with my life (F3);

- So far, I have gotten the important things I want in life (F4);

- If I could live my life over again, I would change almost nothing (F5).

In addition, a single item of the life satisfaction scale asking the respondent to rate his/her satisfaction with life as a whole on a scale from one to 10 (F6) was introduced and compared with the five questions in F1-F5. The literature has shown that this single question is reliable and consistent (Bonikowska et al. 2014). Details on each item included in the Life Satisfaction domain of the questionnaire are provided in Appendix A.1 (Part F).

\subsubsection{Years of good life}

From the indices referring to the four constituent variables discussed above, a binary variable was created for each that indicated whether an individual was below the critical threshold. The cut-offs for the critical threshold are presented in the results section. The binary variable was then aggregated by age and gender. The proportion generated from this dichotomy was then applied to the number of person-years lived in the group, which indicated what portion of remaining life was, on average, spent in good physical and cognitive health, out of absolute poverty and with positive life satisfaction. The life table we used was from the UN World Population Prospects for Thailand, which was disaggregated by gender and 10-year age groups (United Nations 2019a). This method for determining morbidity prevalence was similar to the Sullivan method in (Sullivan 1971).

\section{Results}

\subsection{Descriptive results}

This section presents the distribution of the sample by selected characteristics relevant to YoGL. The results of the current survey were in lieu of observations 
from the PCWAS survey, which was conducted in 2016 across all the regions of Thailand.

\subsubsection{Physical limitations}

In terms of physical limitations, most participants were able to perform the chair stand test, either alone or with assistance (see Figure 3). Only two participants had extreme difficulties or could not perform the test at all, while 28 were able to perform it with some assistance. The participants who were not able to get up from the chair, needed assistance or refused to perform the test were classified as not free from physical limitations in the subsequent YoGL analysis. Less than 5\% of both males and females fell into this category. In terms of demographic heterogeneities, the small sample size did not permit the meaningful disaggregation of the results by age and sex (see Table 1).

In terms of other activities of daily living, Figure 3 shows a breakdown of 12 ADLs by level of difficulty. Most of the participants did not report having difficulties performing basic activities, such as grooming and dressing. Larger shares of participants reported having difficulties performing more strenuous activities, such as walking $1 \mathrm{~km}$, standing for 30 minutes and performing new activities.

\section{Figure 3:}

Prevalence of limitations in activities of daily living (ADLs) by level of difficulty

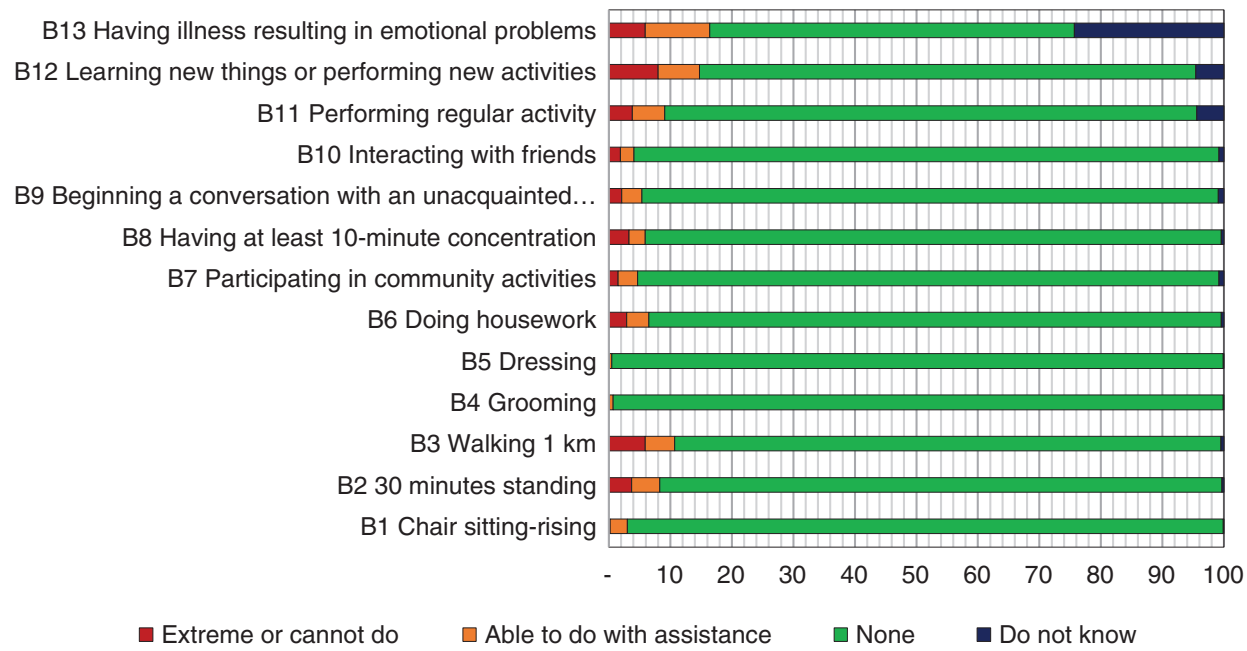

Notes: Item B1 (chair sitting-rising) was objectively assessed by the interviewer. Items in B2 to B12 were assessed based on self-reports by the survey participants. 
Table 1:

Proportion with severe physical limitations by age group and sex

\begin{tabular}{|c|c|c|c|c|c|c|c|c|}
\hline \multirow[b]{2}{*}{ Gender } & \multicolumn{2}{|c|}{ Chair stand (tested) } & \multicolumn{2}{|c|}{ ADLs (5 items) } & \multicolumn{2}{|c|}{ ADLs (12 items) } & \multicolumn{2}{|c|}{ GALI } \\
\hline & $\mathbf{M}$ & $\mathbf{F}$ & $\mathbf{M}$ & $\mathbf{F}$ & $\mathbf{M}$ & $\mathbf{F}$ & $\mathbf{M}$ & $\mathbf{F}$ \\
\hline$<=29$ & 4.76 & 0.00 & 4.76 & 1.96 & 14.29 & 5.88 & 0.00 & 0.00 \\
\hline $30-39$ & 3.85 & 0.00 & 3.85 & 3.37 & 26.92 & 15.73 & 0.00 & 0.00 \\
\hline $40-49$ & 0.00 & 0.00 & 4.35 & 3.65 & 21.74 & 24.09 & 1.45 & 4.38 \\
\hline $50-59$ & 5.00 & 2.21 & 10.00 & 10.50 & 26.25 & 35.91 & 8.75 & 6.63 \\
\hline $60-69$ & 0.00 & 4.14 & 12.20 & 28.28 & 32.93 & 51.03 & 6.10 & 4.83 \\
\hline $70+$ & 4.55 & 17.57 & 18.18 & 44.59 & 36.36 & 70.27 & 4.55 & 10.81 \\
\hline Total & 2.48 & 3.40 & 9.63 & 15.07 & 27.64 & 35.60 & 4.66 & 4.87 \\
\hline
\end{tabular}

Note: Individuals who used assistance to perform the chair stand test were classified as having severe physical limitations. The ADLs were calculated based on items B1-B5 or B1-B12 in the questionnaire. The ADL shares reported in the table reflect the share of respondents who reported having extreme difficulties or who could not perform at least one of the activities without assistance. The GALI was calculated based on item B14 in the questionnaire. The GALI shares reported in the table reflect the share of respondents who reported having severe limitations only.

Table 1 shows a comparison of activity limitations by age and sex based on different indicators. The ADL and GALI (item B14 in the questionnaire) measures were constructed based on being able to perform two or more activities without any assistance. In the sensitivity analysis, the ability to perform at least half of the activities for each composite measure was used to determine whether individuals had physical limitations. This latter composite index has been shown to be statistically similar to the default index.

We can see that there were substantial differences in disability prevalence depending on the choice of indicators. The results of the chair stand test were comparable to those of the five-item list of ADLs among the younger age groups, but not among the older adults. The results of the self-reported GALI question seemed to come closer to those of the chair stand test. As expected, activity limitations were found to increase with age, and more strongly for females than for males.

\subsubsection{Cognitive limitations}

To assess the respondents' cognitive abilities, we performed a series of cognitive tests with different levels of difficulty, and we also asked the respondents to evaluate their own abilities. Table 2 shows that about $63 \%$ of the interviewed individuals reported that they could read/write without any problem, but only $50 \%$ were able to pass the simple reading test. As this means that the respondents had a tendency to overestimate their abilities, the self-reported measures should be treated with caution. Both males and females of all age groups seemed to overestimate their reading abilities (Table 4). For example, only $5 \%$ of males under the age of 30 
Table 2:

Self-reported ability to read (A7) and write (A8) and tested ability to read simple text (C1)

\begin{tabular}{lccc}
\hline & $\begin{array}{c}\text { Self-reported ability } \\
\text { to read (A7) }\end{array}$ & $\begin{array}{c}\text { Self-reported ability to } \\
\text { write (A8) }\end{array}$ & $\begin{array}{c}\text { Tested ability to } \\
\text { read (C1) }\end{array}$ \\
\hline Cannot at all & 13.21 & 9.91 & 19.62 \\
Can with difficulty & 23.42 & 27.63 & 30.13 \\
Can without any problems & 63.36 & 62.46 & 50.25 \\
Total & 100 & 100 & 100 \\
\hline
\end{tabular}

Note: Individuals who were visually impaired or refused to perform the reading test are included in the category "cannot at all". Individuals who were only able to read part of a sentence or almost the whole sentence are included in the category "can with difficulty".

reported that they had difficulties reading, but nearly $20 \%$ could not pass the simple reading test.

Nearly all respondents were able to recognise simple print vocabulary (C4) (99.6\%), and to correctly identify the day of the week (C6) (96.8\%) (Table 3). These two tests measured basic cognitive functioning. A much larger share of respondents were not able to pass the advanced test of reading with understanding (items C5-1 to $\mathrm{C} 5-5$ in the questionnaire). Even among the younger individuals (under age 30), $62 \%$ of males and $51 \%$ of females failed this test. These shares increased to $70 \%$ of males and $92 \%$ of females among the sample of older individuals $(70+)$; see the last two columns of Table 4.

\subsubsection{Poverty}

Different dimensions of absolute poverty were considered in the survey. Two indicators focused on food consumption and dietary diversity (items D1 and D3 in the questionnaire), given that insufficient caloric intake is a key issue in low-

Table 3:

Tested ability to recognise print vocabulary (C4), to read with understanding (C5-1 to C5-5) and to correctly identify the day of the week (C6)

\begin{tabular}{lccccccc}
\hline & C4 & C5-1 & C5-2 & C5-3 & C5-4 & C5-5 & C6 \\
\hline Correct answer & 99.63 & 87.83 & 57.27 & 93.17 & 96.15 & 84.22 & 96.77 \\
Incorrect answer & 0.25 & 8.94 & 39.63 & 3.48 & 0.75 & 12.67 & 3.23 \\
Do not know & 0.12 & 3.23 & 3.11 & 3.35 & 3.11 & 3.11 & 0.00 \\
Total & 100 & 100 & 100 & 100 & 100 & 100 & 100 \\
\hline
\end{tabular}


Table 4:

Proportion with cognitive limitations by age group and sex - self-reported and tested

\begin{tabular}{|c|c|c|c|c|c|c|c|c|}
\hline \multirow[b]{2}{*}{ Gender } & \multicolumn{2}{|c|}{$\begin{array}{c}\text { Self-reported } \\
\text { ability } \\
\text { to read (A7) }\end{array}$} & \multicolumn{2}{|c|}{$\begin{array}{c}\text { Self-reported } \\
\text { ability } \\
\text { to write (A8) }\end{array}$} & \multicolumn{2}{|c|}{$\begin{array}{c}\text { Tested } \\
\text { ability to } \\
\text { read }(\mathrm{C} 1)\end{array}$} & \multicolumn{2}{|c|}{$\begin{array}{l}\text { Tested ability to } \\
\text { read with } \\
\text { understanding } \\
\text { (C5) }\end{array}$} \\
\hline & M & $\mathbf{F}$ & M & $\mathbf{F}$ & M & $\mathbf{F}$ & M & $\mathbf{F}$ \\
\hline$<=29$ & 4.76 & 7.84 & 4.76 & 9.80 & 19.05 & 17.65 & 61.90 & 50.98 \\
\hline 30-39 & 7.69 & 11.24 & 11.54 & 12.36 & 19.23 & 22.47 & 50.00 & 51.69 \\
\hline $40-49$ & 30.43 & 27.01 & 30.43 & 27.74 & 42.03 & 43.07 & 53.62 & 51.82 \\
\hline $50-59$ & 21.25 & 40.88 & 25.00 & 42.54 & 37.50 & 58.56 & 55.00 & 63.54 \\
\hline $60-69$ & 46.34 & 59.31 & 48.78 & 58.62 & 56.10 & 74.48 & 60.98 & 75.86 \\
\hline $70+$ & 45.45 & 75.68 & 45.45 & 72.97 & 59.09 & 74.32 & 70.45 & 91.89 \\
\hline Total & 30.75 & 39.44 & 32.61 & 39.88 & 43.48 & 52.73 & 58.39 & 64.40 \\
\hline
\end{tabular}

Note: Share of respondents who: $\mathrm{A} 7=$ Cannot read at all; $\mathrm{A} 8=$ Cannot write at all; $\mathrm{C} 1=$ Cannot read at all. Tested ability to read with understanding was assessed based on having the correct answers to all included items (C5-1 to C5-5).

and middle-income countries. The results showed that $17 \%$ of respondents reported skipping meals, and $27 \%$ reported limiting the variety of foods they consumed due to a lack of resources (Table 5).

Beyond inadequate food consumption, income-related indicators were also included in the survey, such as ownership of a welfare card (D7), and the subjective evaluation of the individual's financial situation (D8, D9). One-third of the respondents described their financial situation as bad or very bad, and $40 \%$ indicated that their financial situation had become worse over the previous five years. It should be noted that these indicators were subjective, as they relied on the respondent's own evaluations. Around $60 \%$ of the respondents reported receiving financial aid from the government.

Other poverty indicators focused on ownership of specific household assets and living conditions (items G1, G5 and G6 in the questionnaire). Such indicators are often used to assess poverty in low- and middle-income countries, where reporting on income is less reliable (Jolliffe and Prydz 2016). Depending on the specific indicator for household assets or living conditions, the poverty levels varied substantially. Only $4 \%$ of the respondents reported having unfinished walls, and just $4.3 \%$ said they do not own a fridge (Table 5). However, $64 \%$ of the households indicated that do not have a flush toilet, which could be considered a sign of poverty. However, it may also reflect a lack of infrastructure in remote rural areas.

The breakdown by age and gender uncovered no clear pattern of poverty among the population subgroups (Table 6). Based on whether they were skipping meals and had dietary diversity, younger and older individuals were equally likely to be 
Table 5:

Distribution of sample population by poverty measure

\begin{tabular}{lr}
\hline Items & $\%$ \\
\hline Skipping meals in a day because there was not enough food (D1) & \\
Never & 83.18 \\
Yes & 16.82 \\
Limiting variety of foods due to a lack of resources (D3) & \\
Never & 73.37 \\
Yes & 26.63 \\
Owns a welfare card (low-income card) (D7) & \\
No & 39.44 \\
Yes & 60.26 \\
Current financial situation (D8) & \\
Very bad & 4.40 \\
Bad & 27.43 \\
Neither good nor bad & 61.76 \\
Good & 6.21 \\
Very good & 0.20 \\
Financial situation compared to the past 5 years (D9) & \\
Much worse & 3.51 \\
Worse & 27.53 \\
Stayed the same & 30.43 \\
Better & 2.00 \\
Much better & \\
Wall or building material (G1) & \\
Brick, block, stone or cement & 4.30 \\
Wood & 44.14 \\
Half brick, half wood & \\
Makeshift, salvaged or improvised materials from the local & 15.62 \\
$\quad$ area (e.g., plant-based material) & 35.94 \\
Reused materials (e.g, cardboard, scrap) & 0.10 \\
Type of toilet facility (G5) & 4.00 \\
Flush toilet & 63.96 \\
Squat toilet & 11.61 \\
Flush toilet and squat toilet & 0.10 \\
No toilet facility & \\
Owns a fridge (G6) & \\
No & \\
Yes & \\
\hline
\end{tabular}

classified as poor. The exception was among respondents under age 30: in this age group, only $5 \%$ of males, but $14 \%$ of females, reported skipping meals. The likelihood of owning a welfare card was generally higher among the older age groups. Interestingly, younger individuals were more likely than older people to report living in a house without a flush toilet. 
Table 6:

Proportion living in absolute poverty by age group, sex and poverty measure

\begin{tabular}{|c|c|c|c|c|c|c|c|c|}
\hline \multirow[b]{2}{*}{ Gender } & \multicolumn{2}{|c|}{$\begin{array}{c}\text { Skipping } \\
\text { meals (D1) }\end{array}$} & \multicolumn{2}{|c|}{$\begin{array}{c}\text { Dietary } \\
\text { diversity (D3) }\end{array}$} & \multicolumn{2}{|c|}{$\begin{array}{l}\text { Welfare } \\
\text { card (D7) }\end{array}$} & \multicolumn{2}{|c|}{$\begin{array}{c}\text { Flush } \\
\text { toilet (G5) }\end{array}$} \\
\hline & $\mathbf{M}$ & $\mathbf{F}$ & $\mathbf{M}$ & $\mathbf{F}$ & $\mathbf{M}$ & $\mathbf{F}$ & $\mathbf{M}$ & $\mathbf{F}$ \\
\hline$<29$ & 4.76 & 13.73 & 14.29 & 27.45 & 47.62 & 45.10 & 85.71 & 76.47 \\
\hline $30-39$ & 19.23 & 17.98 & 23.08 & 31.46 & 46.15 & 59.55 & 46.15 & 70.79 \\
\hline $40-49$ & 23.19 & 17.52 & 24.64 & 24.82 & 49.28 & 64.96 & 71.01 & 69.34 \\
\hline $50-59$ & 13.75 & 19.34 & 25.00 & 34.25 & 58.75 & 59.12 & 63.75 & 63.54 \\
\hline 60-69 & 18.29 & 13.79 & 26.83 & 24.14 & 74.39 & 64.83 & 60.98 & 57.93 \\
\hline $70+$ & 20.45 & 12.16 & 13.64 & 25.68 & 65.91 & 62.16 & 63.64 & 50.00 \\
\hline Total & 17.70 & 16.40 & 22.98 & 28.36 & 59.94 & 60.86 & 64.60 & 63.96 \\
\hline
\end{tabular}

\subsubsection{Life satisfaction}

The final dimension of YoGL concerns the respondents' subjective evaluation of their own life. One way to capture this dimension was by asking the respondents about their overall life satisfaction on a scale from one to 10 (item F6 in the questionnaire). Depending on the cut-off point at which life satisfaction was assessed, the overall share of individuals reporting that they are not satisfied with life ranged from $2 \%$ to nearly $21 \%$ for males and from $3 \%$ to $20 \%$ for females (Table 7). No clear trend across age groups could be observed.

Alternative questions concerning life satisfaction are presented in Figure 4. Between $8 \%$ and $24 \%$ of the respondents reported that they are not satisfied with certain aspects of their life (strongly disagreeing or disagreeing with the

Table 7:

Proportion unsatisfied with life by sex

\begin{tabular}{|c|c|c|c|c|c|c|}
\hline \multirow[b]{2}{*}{ Gender } & \multicolumn{2}{|c|}{$\begin{array}{c}\text { Life satisfaction } \\
(\text { F6 score }<4)\end{array}$} & \multicolumn{2}{|c|}{$\begin{array}{c}\text { Life satisfaction } \\
(\text { F6 score }<5)\end{array}$} & \multicolumn{2}{|c|}{$\begin{array}{c}\text { Life satisfaction } \\
(\text { F6 score }<6)\end{array}$} \\
\hline & $\mathbf{M}$ & $\mathbf{F}$ & $\mathbf{M}$ & F & $\mathbf{M}$ & F \\
\hline$<=29$ & 0 & 3.92 & 0.00 & 3.92 & 19.05 & 21.57 \\
\hline $30-39$ & 0 & 2.15 & 0.00 & 5.62 & 15.38 & 19.10 \\
\hline $40-49$ & 0 & 0.73 & 8.70 & 2.92 & 21.74 & 21.90 \\
\hline $50-59$ & 3.75 & 3.87 & 6.25 & 7.18 & 20.00 & 20.44 \\
\hline $60-69$ & 3.66 & 3.45 & 4.88 & 5.52 & 23.17 & 20.00 \\
\hline $70+$ & 0 & 2.70 & 2.27 & 5.41 & 18.18 & 17.57 \\
\hline Total & 1.86 & 2.81 & 4.97 & 5.32 & 20.50 & 20.24 \\
\hline
\end{tabular}


Figure 4:

Life satisfaction by level of agreement

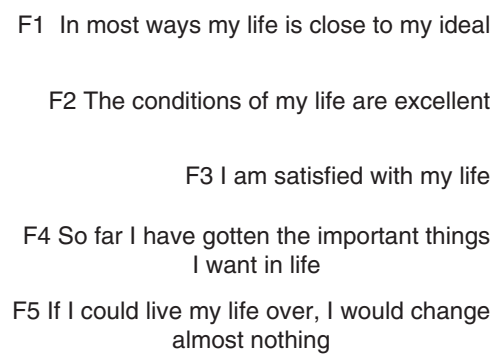

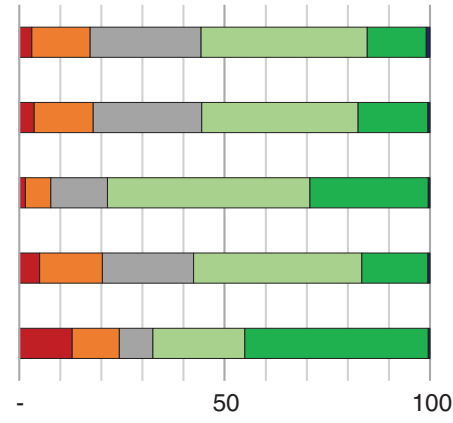

$\square$ Disagree

$\square$ Agree

Don't know

statements). A large share of individuals (24\%) reported that they would like to change something if they could live their life over again.

\subsection{Years of Good Life (YoGL)}

The main results presented in this section are based on a set of preferred indicators for each dimension of YoGL. The alternative measures described in the previous section were used in a series of sensitivity analyses (see Section 3.3), and demonstrate how YoGL can be adapted for different contexts. For the main results, the following measures (and cut-off points) were selected in each dimension:

- Physical health: Can stand up from a chair without assistance.

- Cognitive health: Can read a full sentence (tested).

- Out of poverty: Does not skip meals.

- Life satisfaction: Reports a life satisfaction score of five or higher.

In the physical health dimension, the chair stand test was selected because its distribution was observed to represent the tail ends, or those who were in relatively poor condition. In addition, the chair stand test was utilised in the seminal study that demonstrated YoGL as a well-being indicator (Lutz et al. 2021). For testing the respondents' cognitive health, the ability to read was selected as the measure for YoGL because it did not suffer from reporting error. Poverty was assessed based on the measure of not skipping meals. This measure was preferred to measures of household assets and living conditions because it reflected individual poverty, and allowed for differences between males and females within the same household. 
Figure 5:

YoGL and individual dimensions at age 20 by sex

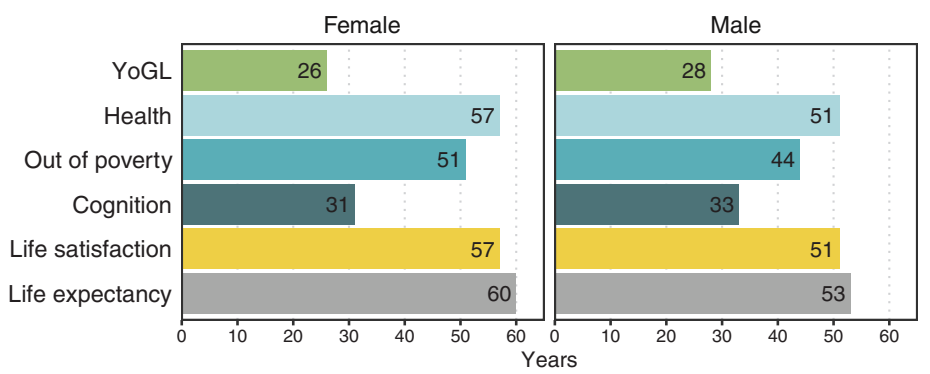

Notes: Life expectancy by five-year age group and sex for Thailand was retrieved from the United Nations World Population Prospects (https://population.un.org/wpp/Download/Standard/Population/).

Finally, to measure life satisfaction, the item with a 10-point scale response category was selected because of its comparability with the measures used in previous studies on YoGL (Lutz et al. 2021). Detailed information about the share of individuals with positive scores on each YoGL dimension by age and sex is provided in Appendix A.2, Table A.2.

When the four constituent dimensions of YoGL were integrated into life expectancy at age 20, the years of good life among women and men were similar: 26 years for women and 28 years for men (Figure 5). Compared to the overall life expectancy at age 20, which was 60 years for women and 53 years for men, we can see that years of good life were lost in each YoGL dimension. Cognitive health was the dimension that reduced the years of good life the most for both sexes (by 29 years for females, and by 20 years for males). In contrast, relatively few years of good life were lost to poor health, low life satisfaction and poverty.

In the context of Thailand, this is the first study to present an integrated view of years of good life in terms of physical health, cognition, life satisfaction and poverty. Previous studies have estimated healthy life expectancy (HLE) in Thailand using comparative characteristics, such as living in an urban or a rural area (Karcharnubarn et al. 2013), or betweeen men and women (Apinonkul et al. 2015). While HLE is useful for determining years without health limitations, it does not explicitly account for other sources of health gradients, such as poverty.

Other studies focused on the older Thai population have tried to identify health determinants and their contributions to healthy years. It has, for example, been observed that individuals with higher levels of income and education have advantages in delaying the onset of physical limitations (Pothisiri et al. 2020) and the decline in cognitive performance (Vicerra and Pothisiri 2020). The approach these studies employed was different, as they compared the health performance of a set of socio-economic subgroups. For example, the years of advantage gained by individuals with higher educational attainment levels were comparable to those 
gained by individuals with lower levels of education. Individual indices within YoGL also allow for the comparison of years of good life between subpopulations. The difference with previous methods is that those respective indices of physical and cognitive health measures can be constructed into a complete indicator which also accounts for poverty and life satisfaction.

\subsection{Sensitivity analysis}

We tested the sensitivity of the main YoGL results presented above using different specifications in each YoGL dimension. First, we changed the cut-off points used in the dichotomisation of the health, cognition and life satisfaction measures. Second, we replaced the indicators used in each dimension with alternative indicators, which were discussed in Section 3.1 above. The results of the sensitivity analyses are presented below. Details about the indicators and cut-off points used in each sensitivity analysis are presented in Appendix A.2.

\subsubsection{Alternative cut-offs}

In a first robustness check, we changed the health measure specification by considering people who used assistance to get out of a chair as healthy. The results for women did not change, and men gained one year of good life (Figure 6, Sensitivity 1). In a second sensitivity test, we changed the specification of the cognitive ability measure by considering people who could read only parts of a sentence as cognitively able. This time, the results changed substantially, with women gaining 12 additional years of good life, and men gaining 10 years (Figure 6, Sensitivity 2). Finally, we changed the cut-off points for the life satisfaction measure by considering individuals who reported a score of four and above (Sensitivity 3) or of six and above (Sensitivity 4) as satisfied. The YoGL results were not noticeably affected in Sensitivity 3, and were only slightly reduced in Sensitivity 4 (Figure 6).

\subsubsection{Alternative indicators}

We also tested the robustness of the results by replacing the measures used in individual YoGL dimensions with alternative measures. For the physical health dimension, we considered five-item and 12-item ADLs, as well as GALI measures. It should be noted that these three measures were based on self-reported health, rather than on tested health. While no notable change in YoGL was observed when using the GALI and the five-item ADLs, the 12-item ADLs reduced YoGL by six years for women and by five years for men (Figure 7, Sensitivity 5-7). These findings reflect the fact that older adults, and especially women, had a tendency to report more limitations in performing activities of daily living (Table 1). 
Figure 6:

YoGL at age 20 by sex calculated with alternative cut-offs for the indicators in the individual dimensions

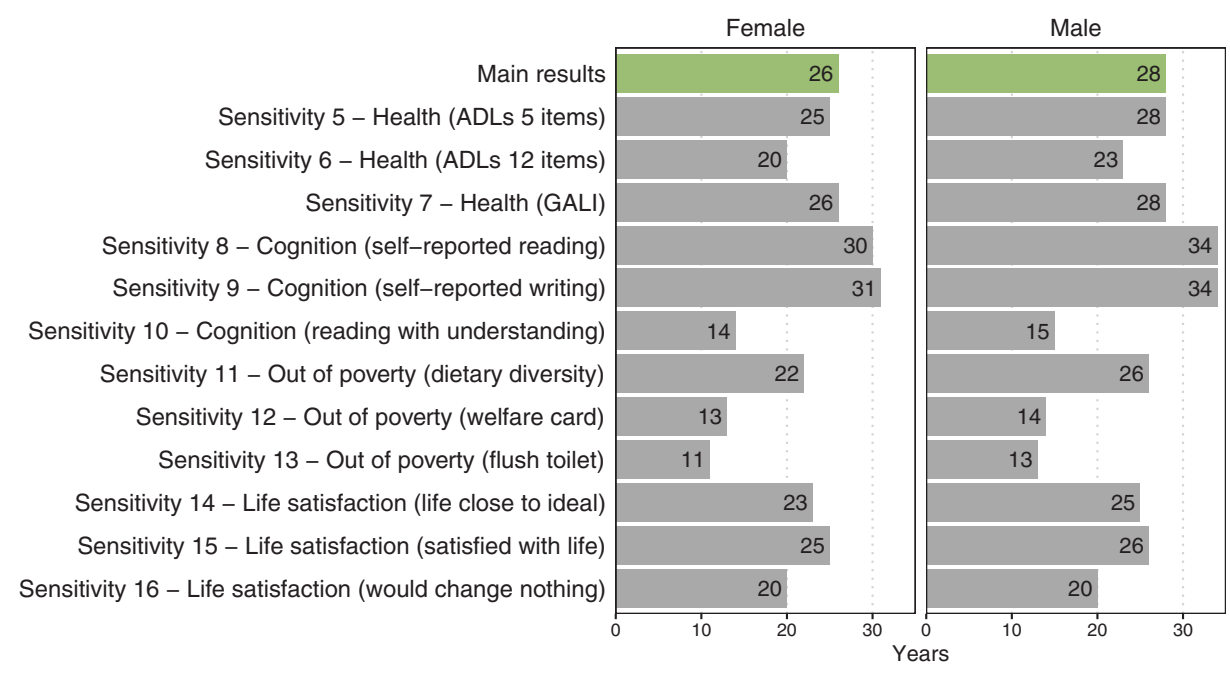

Notes: Bars show YoGL calculated with the preferred cut-offs for each indicator (green bar), and by replacing the cut-offs for one indicator at a time (grey bars).

In addition, we found that the respondents' self-assessments of their ability to read overestimated their true ability to read, as some of the individuals who indicated that they could read were unable to perform the reading test when presented with the opportunity. When we used the self-reported reading and writing measures for calculating YoGL, years of good life improved by four years for women and by six years for men (Figure 7, Sensitivity 8-9). This indicates that men tended to overestimate their reading and writing skills more than women. When we used the more complex test of reading with understanding instead of the simple reading test, years of good life at age 20 were reduced to only 14 years for women and to 15 years for men (Sensitivity 10).

Different measures for poverty were also tested. Using a measure for dietary diversity instead of meal frequency did not noticeably change the results. However, when we applied measures based on ownership of a welfare card and having a flush toilet, years of good life were reduced substantially for both men and women (Figure 7, Sensitivity 11-13).

Finally, we tested the robustness of our main YoGL results by using different life satisfaction measures (Figure 7, Sensitivity 14-16). The different specifications did not substantially change the results, with the exception of the life satisfaction measure based on the following statement: "If I could live my life over, I would 
Figure 7:

YoGL at age 20 by sex calculated with alternative indicators in the individual dimensions

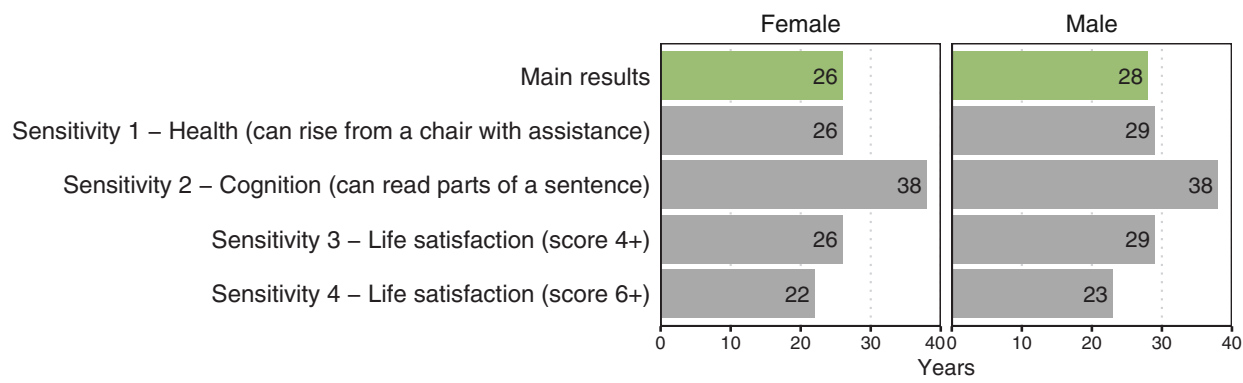

Notes: Bars show YoGL calculated with the preferred indicators (green bar) and by replacing one indicator at a time (grey bars).

change almost nothing". A larger share of individuals reported having lower life satisfaction based on this measure than on the other life satisfaction measures, which resulted in lower YoGL for both sexes (Sensitivity 16).

\section{Conclusion}

As the economy of Thailand continues to grow, it is often assumed that human development in the country has been increasing as well. But because this perspective masks the heterogeneity of the population, the varying levels of poverty experienced by people with different characteristics are not granted sufficient attention. We addressed this issue by utilising the YoGL as a well-being indicator. Gathering data from Chiang Rai and Kalasin, which are located in regions of the country with a high prevalence of poverty, we demonstrated the extent to which social and economic indicators contributed to years of good life among a sample of men and women.

The application of YoGL as a well-being indicator was demonstrated in this study based on survey data collected from two province in Thailand. This "bottom-up" approach to measuring human well-being is flexible, and can easily be applied to different development contexts and population subgroups. While the sample used in this study was sufficient for the purposes of this project, its generalisability is limited. The collection of larger samples would allow for more in-depth comparisons to be made across population subgroups. In this paper, we demonstrated how YoGL can be used to compare the well-being of men and women. This approach can also be used to investigate heterogeneities based on level of education, residence status and occupational status, among many other characteristics. The techniques used to construct YoGL allow for such comparisons to be made between population 
subgroups and over time. Moreover, the individual constituents of YoGL can be examined to determine the sources of these heterogeneities.

\section{References}

Apinonkul, B., K. Soonthorndhada, P. Vapattanawong, W. Aekplakorn and C. Jagger 2015. Gender differences in health expectancies across the disablement process among older Thais. PLOS ONE 10(3): e0121310. https://doi.org/10.1371/journal.pone.0121310

Bonikowska, A., J. F. Helliwell, F. Hou and G. Schellenberg 2014. An assessment of life satisfaction responses on recent Statistics Canada Surveys. Social Indicators Research 118(2): 617-643. https://doi.org/10.1007/s11205-013-0437-1

Chakravarty, S. R. 2017. Analyzing multidimensional well-being: A quantitative approach. John Wiley \& Sons. https://doi.org/10.1002/9781119257424

Dasgupta, P. 2004. Human well-being and the natural environment. Oxford University Press. https://doi.org/10.1093/0199247889.001.0001

Desai, M., A. Sen and J. Boltvinik 1992. Social progress index: A proposal. Bogota: United Nations Development Programme.

Lok-Dessallien, R. 2000. Review of poverty concepts and indicators. New York: United Nations Development Programme.

Diener, E., S. J. Heintzelman, K. Kushlev, L. Tay, D. Wirtz, L. D. Lutes and S. Oishi 2017. Findings all psychologists should know from the new science on subjective well-being. Canadian Psychology/Psychologie Canadienne 58(2): 87-104. https://doi.apa.org/doi/10. 1037/cap0000063

Diener, E., E. M. Suh, R. E. Lucas and H. L. Smith 1999. Subjective well-being: Three decades of progress. Psychological Bulletin 125(2): 276-302. https://psycnet.apa.org/doi/ 10.1037/0033-2909.125.2.276

Easterlin, R. A. 1974. Does economic growth improve the human lot? Some empirical evidence. In: Nations and households in economic growth: Essays in honor of Moses Abramovitz, eds P. A. David and M. W. Reder, 89-125. Academic Press. https://doi.org/ 10.1016/B978-0-12-205050-3.50008-7

Ferreira, F. H. G., S. Chen, A. Dabalen, Y. Dikhanov, N. Hamadeh, D. Jolliffe, A. Narayan, E. B. Prydz, A. Revenga, P. Sangraula, U. Serajuddin and N. Yoshida 2016. A global count of the extreme poor in 2012: Data issues, methodology and initial results. The Journal of Economic Inequality 14(2): 141-172. https://doi.org/10.1007/s10888-016-9326-6

Frey, B. S. and A. Stutzer 2002. What can economists learn from happiness research? Journal of Economic Literature 40(2): 402-435.

Ghislandi, S., W. C. Sanderson and S. Scherbov 2019. A simple measure of human development: The Human Life Indicator. Population and Development Review 45(1): 219-233. https://doi.org/10.1111/padr.12205

Gil Sander, F. and A. Burgard 2011. Thailand economic monitor: April 2011. Washington, D.C.

Jagger, C., C. Gillies, E. Cambois, H. Van Oyen, W. Nusselder and J. M. Robine 2010. The global activity limitation index measured function and disability similarly across 
European countries. Journal of Clinical Epidemiology 63(8): 892-899. https://doi.org/10. 1016/j.jclinepi.2009.11.002

Jolliffe, D. and E. B. Prydz 2016. Estimating international poverty lines from comparable national thresholds. Policy Research Working Paper No. 7606. Washington, D.C.: World Bank. http://hdl.handle.net/10986/24148

Kahneman, D. 1999. Objective happiness. In: Well-being: The foundations of hedonic psychology, eds D. Kahneman, E. Diener and N. Schwarz, 3-25. New York: Russell Sage Foundation.

Karcharnubarn, R., P. Rees and M. Gould 2013. Healthy life expectancy changes in Thailand, 2002-2007. Health and Place 24:1-10. https://doi.org/10.1016/j.healthplace.2013.08.002

Larsen, R. J., E. D. Diener and R. A. Emmons 1985. An evaluation of subjective well-being measures. Social Indicators Research 17: 1-17. https://doi.org/10.1007/BF00354108

Lorenz, J., C. Brauer and D. Lorenz 2017. Rank-optimal weighting or "How to be best in the OECD better life index?” Social Indicators Research 134(1): 75-92. https://doi.org/10. 1007/s11205-016-1416-0

Lutz, W., A. A. Lijadi, E. Strießnig, A. Dimitrova and M. Caldeira Brant de Souza Lima 2018. Years of Good Life (YoGL): A new indicator for assessing sustainable progress. IIASA Working Paper WP-18-007. Laxenburg, Austria: International Institute of Applied Systems Analysis. http://pure.iiasa.ac.at/id/eprint/15402/1/WP-18-007.pdf

Lutz, W., E. Striessnig, A. Dimitrova, S. Ghislandi, A. Lijadi, C. Reiter, S. Spitzer and D. Yildiz 2021. Years of good life is a well-being indicator designed to serve research on sustainability. Proceedings of the National Academy of Sciences 118(12): e1907351118. https://doi.org/10.1073/pnas.1907351118

Mascarenhas, A., P. Coelho, E. Subtil and T. B. Ramos 2010. The role of common local indicators in regional sustainability assessment. Ecological Indicators 10(3): 646-656.

McGregor, J. A. 2008. Wellbeing, development and social change in Thailand. Thammasat Economic Journal 26(2): 1-27.

Mclean, D. 2014. National and international indices of well-being: A critical analysis. Journal of the Indiana Academy of the Social Sciences 17(1): 5.

OPHI 2009. Measuring multidimensional poverty: Insights from around the world. OPHI Briefing 30. Oxford: Oxford Poverty and Human Development Initiative (OPHI), University of Oxford.

Pavot, W. and E. Diener 1993. Review of the satisfaction with life scale. Psychological Assessment 5(2): 164-172. https://psycnet.apa.org/doi/10.1037/1040-3590.5.2.164

Pavot, W. and E. Diener 2008. The satisfaction with life scale and the emerging construct of life satisfaction. The Journal of Positive Psychology 3(2): 137-152. https://doi.org/10. 1080/17439760701756946

Pierre, G., M. Laura Sanchez Puerta, A. Valerio and T. Rajadel 2013. STEP skills measurement surveys: Innovative tools for assessing skills. Social Protection and Labor Discussion Paper 1421 Washington, D.C.: World Bank Group.

Pothisiri, W., O. Prasitsiriphon and W. Aekplakorn 2020. Extent of aging across education and income subgroups in Thailand: Application of a characteristic-based age approach. PLoS ONE 15(12): e0243081. https://doi.org/10.1371/journal.pone.0243081 
Salomon, J. A., H. Wang, M. K. Freeman, T. Vos, A. D. Flaxman, A. D. Lopez and C. J. L. Murray 2012. Healthy life expectancy for 187 countries, 1990-2010: A systematic analysis for the Global Burden Disease Study 2010. The Lancet 380(9859): 2144-2162. https://doi.org/10.1016/S0140-6736(12)61690-0

Spitzer, S. and D. Weber 2019. Reporting biases in self-assessed physical and cognitive health status of older Europeans. PLoS ONE 14(10): e0223526. https://doi.org/10.1371/ journal.pone. 0223526

Stiglitz, J., A. Sen and J. P. Fitoussi 2010. Mismeasuring our lives: Why GDP doesn't add up. The New Press.

Strezov, V., A. Evans and T. J. Evans 2017. Assessment of the economic, social and environmental dimensions of the indicators for sustainable development. Sustainable Development 25(3): 242-253. https://doi.org/10.1002/sd.1649

Sullivan, D. F. 1971. A single index of mortality and morbidity. HSMHA Health Reports 86(4): 347-354.

United Nations 2019a. 2019 Revision of World Population Prospects. Retrieved from https: //population.un.org/wpp/

United Nations 2019b. World Urbanization Prospects: The 2018 Revision. New York: United Nations.

Üstün, T. B., N. Kostanjsek, S. Chatterji and J. Rehm 2010. Measuring health and disability: Manual for WHO Disability Assessment Schedule (WHODAS 2.0). World Health Organization. https://apps.who.int/iris/handle/10665/43974

Veneri, P. and A. J. E. Edzes 2017. Well-being in cities and regions: Measurement, analysis and policy practices. Region 4(2): E1-E5. https://doi.org/10.18335/region.v4i2.188

Vicerra, P. M. M. and W. Pothisiri 2020. Trajectories of cognitive ageing among Thai laterlife adults: The role of education using the characteristics approach. Journal of Population and Social Studies 28(4): 276-286. https://doi.org/10.25133/JPSSv28n4.019

Weber, D. 2016. Differences in physical aging measured by walking speed: Evidence from the English Longitudinal Study of Ageing. BMC Geriatrics 16(1): 31. https://doi.org/10. 1186/s12877-016-0201-X

Weeranakin, P. and B. Promphakping 2018. Local meanings of wellbeing and the construction of wellbeing indicators. Social Indicators Research 138(2): 689-703. https://doi.org/10. 1007/s11205-017-1692-3

World Bank 2019. World Bank Open Data. https://data.worldbank.org/

Yang, J., S. Wang and R. Dewina 2020. Taking the pulse of poverty and inequality in Thailand. Washington, D.C.: World Bank Group. 


\section{Appendix A.1: Questionnaire}

\section{Part A - Demographic characteristics}

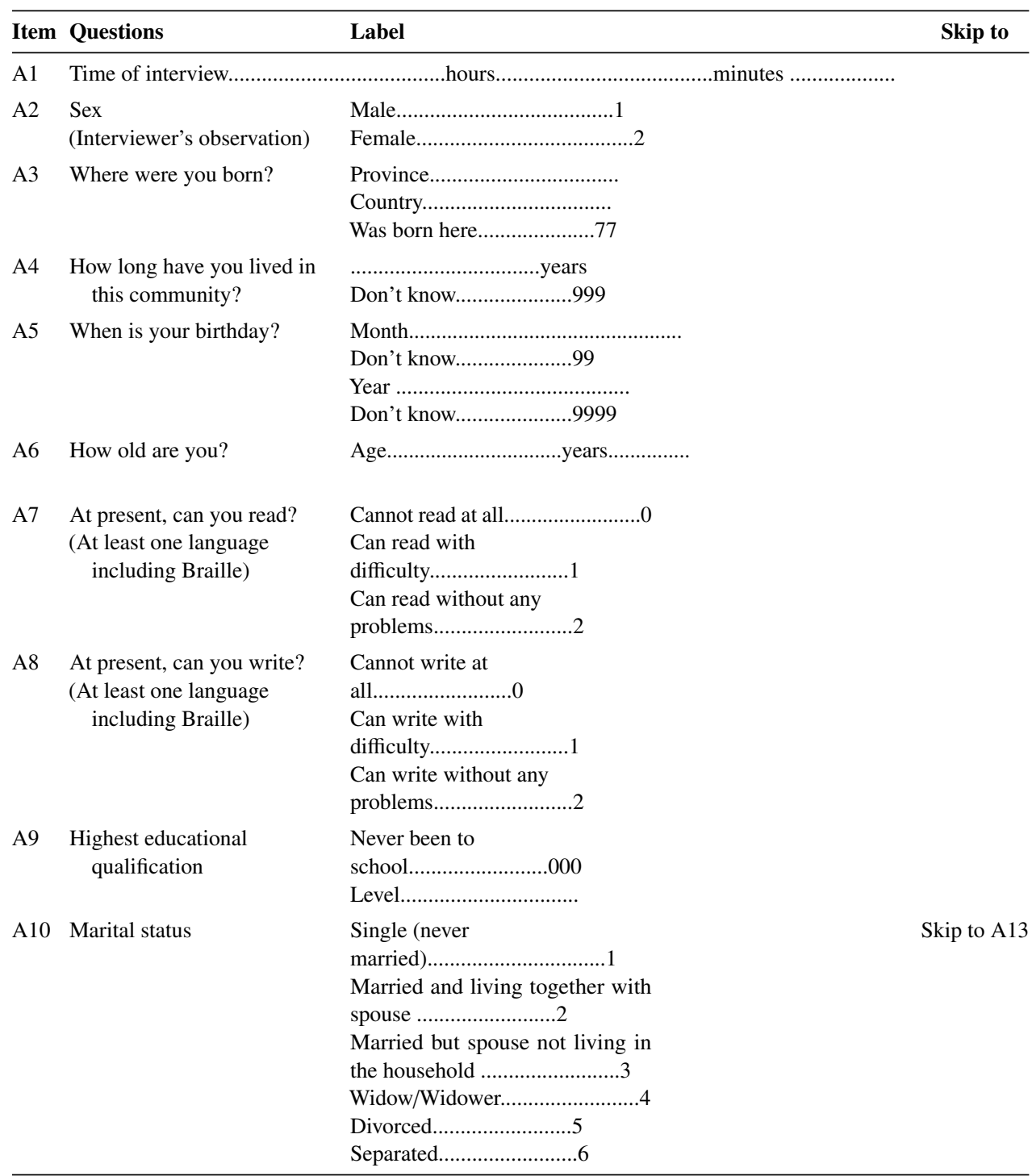

Continued 


\section{Part A - Continued}

\begin{tabular}{|c|c|c|c|}
\hline Item & Questions & Label & Skip to \\
\hline A11 & $\begin{array}{l}\text { How many living children do } \\
\text { you currently have? }\end{array}$ & 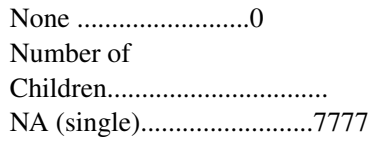 & \\
\hline A12 & $\begin{array}{l}\text { Any sons or daughters who } \\
\text { have died }\end{array}$ & 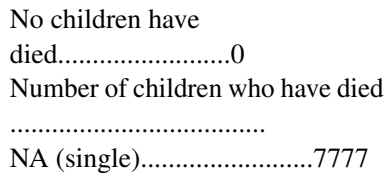 & \\
\hline A13 & $\begin{array}{l}\text { What is your main } \\
\text { occupation? }\end{array}$ & $\begin{array}{l}\text { Currently not } \\
\text { working......................... } 0 \\
\text { Studying ..................... } 1 \\
\text { Please specify occupation }\end{array}$ & $\begin{array}{l}\text { Skip to B1 } \\
\text { Skip to B1 }\end{array}$ \\
\hline A14 & Working status & 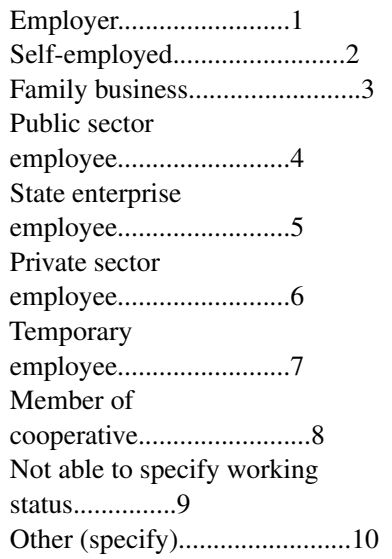 & \\
\hline
\end{tabular}

\section{Part B - Health}

\begin{tabular}{|c|c|c|c|}
\hline Item & Questions & Label & Skip to \\
\hline \multirow[t]{4}{*}{ B1 } & Chair rise (Please & Extreme or cannot do......................... 1 & \\
\hline & Test) & Able to do with assistance........................... & \\
\hline & & None of difficulty............................ 3 & \\
\hline & & Refuse to do the test......................... 7 & \\
\hline
\end{tabular}




\begin{tabular}{|c|c|c|c|c|c|}
\hline Item & $\begin{array}{l}\text { In the past } 30 \text { days, how much } \\
\text { difficulty did you have in: } \\
\text { Please choose the } \\
\text { appropriate answers below: }\end{array}$ & None & $\begin{array}{l}\text { Able to do } \\
\text { with assistance }\end{array}$ & $\begin{array}{l}\text { Extreme or } \\
\text { cannot do }\end{array}$ & NA \\
\hline B2 & $\begin{array}{l}\text { Standing for long periods such as } \\
30 \text { minutes }\end{array}$ & 3 & 2 & 1 & 7 \\
\hline B3 & $\begin{array}{l}\text { Walking a long distance such as a } \\
\text { kilometer [or equivalent] }\end{array}$ & 3 & 2 & 1 & 7 \\
\hline B4 & Washing your whole body & 3 & 2 & 1 & 7 \\
\hline B5 & Getting dressed & 3 & 2 & 1 & 7 \\
\hline B6 & $\begin{array}{l}\text { Taking care of your household } \\
\text { responsibilities }\end{array}$ & 3 & 2 & 1 & 7 \\
\hline B7 & $\begin{array}{l}\text { Joining in community activities } \\
\text { (for example, festivities, } \\
\text { religious, or other activities) } \\
\text { in the same way as anyone } \\
\text { else can }\end{array}$ & 3 & 2 & 1 & 7 \\
\hline B8 & $\begin{array}{l}\text { Concentrating on doing } \\
\text { something for } 10 \text { minutes }\end{array}$ & 3 & 2 & 1 & 7 \\
\hline B9 & $\begin{array}{l}\text { Dealing with people you do not } \\
\text { know }\end{array}$ & 3 & 2 & 1 & 7 \\
\hline B10 & Maintaining a friendship & 3 & 2 & 1 & 7 \\
\hline B11 & Your day-to-day work/school & 3 & 2 & 1 & 7 \\
\hline B12 & $\begin{array}{l}\text { Learning a new task, for example, } \\
\text { learning how to get to a new } \\
\text { place }\end{array}$ & 3 & 2 & 1 & 7 \\
\hline B13 & $\begin{array}{l}\text { How much have you been } \\
\text { emotionally affected by your } \\
\text { health problems }\end{array}$ & 3 & 2 & 1 & 7 \\
\hline
\end{tabular}

\begin{tabular}{|c|c|c|c|}
\hline Item & Questions & Label & Skip to \\
\hline B14 & $\begin{array}{l}\text { For at least the past six } \\
\text { months, to what } \\
\text { extent have you } \\
\text { been limited } \\
\text { because of a health } \\
\text { problem in } \\
\text { activities people } \\
\text { usually do? }\end{array}$ & 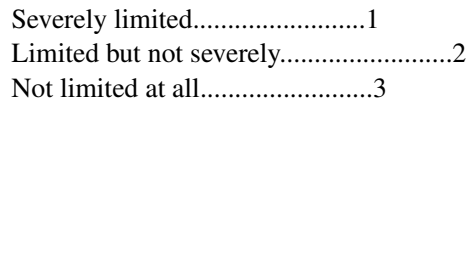 & \\
\hline B15 & $\begin{array}{l}\text { Could you tell us until } \\
\text { which age do you } \\
\text { think you will live? }\end{array}$ & $\begin{array}{l}\text { Will live until........................years } \\
\text { Don't know....................... } \\
\text { Up to god..................... } \\
\text { No one know when he/she } \\
\text { will die......................2 }\end{array}$ & \\
\hline
\end{tabular}




\section{Part C - Literacy}

\begin{tabular}{|c|c|c|c|}
\hline Item & Questions & Label & Skip to \\
\hline $\mathrm{C} 1$ & $\begin{array}{l}\text { Now I would like you } \\
\text { to read this sentence } \\
\text { to me. }\end{array}$ & 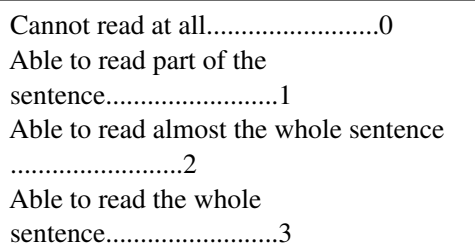 & Skip to D1 \\
\hline & & 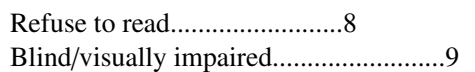 & $\begin{array}{l}\text { Skip to D1 } \\
\text { Skip to D1 }\end{array}$ \\
\hline
\end{tabular}

\section{Texts for $\mathrm{C} 1$}

"ชาวนาเป็นอาชีพที่ต้องทำงานหนัก"

“นักเรียนสอบได้คะแนนยอดเยี่ยม"

"เสร็จแล้วไซร้เดินหน้ายุ่งเข้ามุ้งนอน"
Rice farming is a hard work.

The student passed the exam with an excellent score.

After he finished work, he went to bed.

\begin{tabular}{|c|c|c|c|}
\hline Item & Question & Label & Skip to \\
\hline $\mathrm{C} 4$ & Circle the word that matches the picture: & 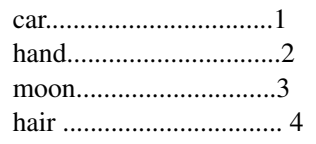 & \\
\hline
\end{tabular}

\begin{tabular}{|c|c|c|c|}
\hline Item & $\begin{array}{l}\text { Read the sentences below. Circle YES if the sentence makes sense. } \\
\text { Circle NO if the sentence does not make sense. }\end{array}$ & No & Yes \\
\hline \multirow[t]{6}{*}{ C5 } & 1. ลูกบอลมีทรงสี่เหลี่ยม & 1 & 2 \\
\hline & A ball has a square shape. & & \\
\hline & 2. ลูกชายของน้องสาว คือ หลานสาวของเรา & 1 & 2 \\
\hline & $\begin{array}{l}\text { The son of my sister is my niece. } \\
\text { 3. สีเขียว คือ สัญญาณไฟจราจรให้รถไปได้ }\end{array}$ & 1 & 2 \\
\hline & $\begin{array}{l}\text { When the traffic light turns green, cars can go. } \\
\text { 4. นกเป็นสัตว์ที่บินได้ } \\
\text { A bird can fly. }\end{array}$ & 1 & 2 \\
\hline & $\begin{array}{l}\text { 5. ข้าวสารหนัก } 50 \text { กิโลกรัม หนักกว่าข้าวสาร } 70 \text { กิโลกรัม } \\
\text { A } 50 \text { kilograms bag of rice is heavier than a } 70 \\
\text { kilograms bag of rice. }\end{array}$ & 1 & 2 \\
\hline
\end{tabular}




\begin{tabular}{|c|c|c|}
\hline Item & Question & Label \\
\hline C6 & Can you tell me what day of the week it is? & $\begin{array}{l}\text { Day of week given } \\
\text { correctly............................1 } \\
\text { Day of week given incorrectly/doesn't } \\
\text { know day.............................. }\end{array}$ \\
\hline
\end{tabular}

\section{Part D - Economic conditions}

\begin{tabular}{|c|c|c|c|}
\hline Item & Questions & Label & Skip to \\
\hline D1 & $\begin{array}{l}\text { In the past four weeks, did you or any } \\
\text { household member have to eat } \\
\text { fewer meals in a day because there } \\
\text { was not enough food? }\end{array}$ & 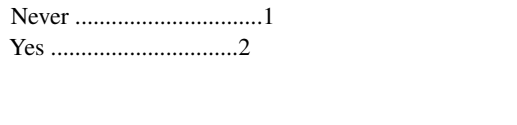 & Skip to D3 \\
\hline D2 & $\begin{array}{l}\text { How often did this happen in the } \\
\text { past four weeks? }\end{array}$ & $\begin{array}{l}\text { Rarely } \\
\text { (once or twice in the past for weeks)....1 } \\
\text { Sometimes } \\
\text { (three to } 10 \text { times in the past for weeks)...2 } \\
\text { Often } \\
\text { (More than } 10 \text { times in the past for weeks) }\end{array}$ & \\
\hline D3 & $\begin{array}{l}\text { In the past four weeks, did you or any } \\
\text { household member have to eat a } \\
\text { limited variety of foods due to a } \\
\text { lack of resources? }\end{array}$ & 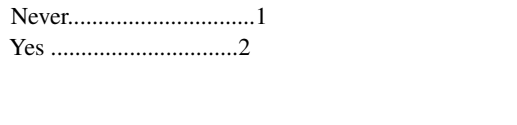 & Skip to D5 \\
\hline D4 & $\begin{array}{l}\text { How often did this happen in the } \\
\text { past four weeks? }\end{array}$ & $\begin{array}{l}\text { Rarely } \\
\text { (once or twice in the past for weeks)....1 } \\
\text { Sometimes } \\
\text { (three to } 10 \text { times in the past for weeks)...2 } \\
\text { Often } \\
\text { (More than } 10 \text { times in the past for } \\
\text { weeks)........................... } 3\end{array}$ & \\
\hline D5 & $\begin{array}{l}\text { In the past } 12 \text { months, how much did } \\
\text { you earn in all of your jobs? } \\
\text { (including non-monetary income) }\end{array}$ & 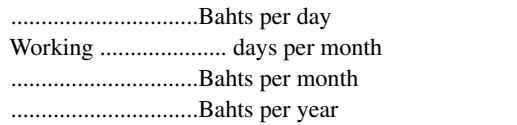 & \\
\hline D6 & $\begin{array}{l}\text { Do you think that your total income is } \\
\text { enough for a living? }\end{array}$ & 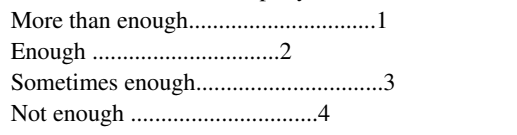 & \\
\hline D7 & $\begin{array}{l}\text { Do you have a welfare card } \\
\text { (low-income card)? }\end{array}$ & 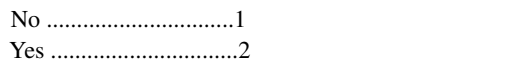 & \\
\hline D8 & $\begin{array}{l}\text { How is the current financial situation } \\
\text { of your household? }\end{array}$ & 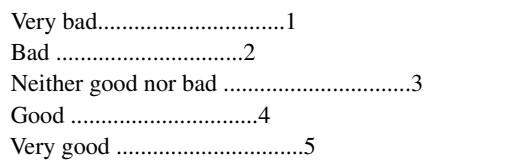 & \\
\hline D9 & $\begin{array}{l}\text { Compared to the past five years } \\
\text { (2013), did the financial situation } \\
\text { of your household get...? }\end{array}$ & 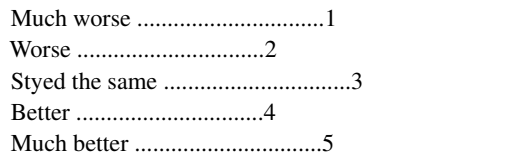 & \\
\hline
\end{tabular}




\section{Part F - Satisfaction with life}

Using the 1-5 scale below, indicate your agreement with each item by placing the appropriate number on the line preceding that item. Please be open and honest in your responding.

\begin{tabular}{|c|c|c|c|c|c|c|}
\hline Item & $\begin{array}{c}\text { Strongly } \\
\text { agree }\end{array}$ & Agree & $\begin{array}{l}\text { Neither agree } \\
\text { nor disagree }\end{array}$ & Disagree & $\begin{array}{l}\text { Strongly } \\
\text { disagree }\end{array}$ & Don't know \\
\hline \multirow[t]{2}{*}{ F1 } & \multicolumn{6}{|c|}{ In most ways my life is close to my ideal. } \\
\hline & 5 & 4 & 3 & 2 & 1 & 9 \\
\hline \multirow[t]{2}{*}{ F2 } & \multicolumn{6}{|c|}{ The conditions of my life are excellent. } \\
\hline & 5 & 4 & 3 & 2 & 1 & 9 \\
\hline \multirow[t]{2}{*}{$\mathbf{F 3}$} & \multicolumn{6}{|c|}{ I am satisfied with my life. } \\
\hline & 5 & 4 & 3 & 2 & 1 & 9 \\
\hline \multirow[t]{2}{*}{ F4 } & \multicolumn{6}{|c|}{ So far I have gotten the important things I want in life. } \\
\hline & 5 & 4 & 3 & 2 & 1 & 9 \\
\hline \multirow[t]{2}{*}{ F5 } & \multicolumn{6}{|c|}{ If I could live my life over, I would change almost nothing. } \\
\hline & 5 & 4 & 3 & 2 & 1 & 9 \\
\hline
\end{tabular}

F6 Taking all things together, how satisfied are you with your life as a whole these days?

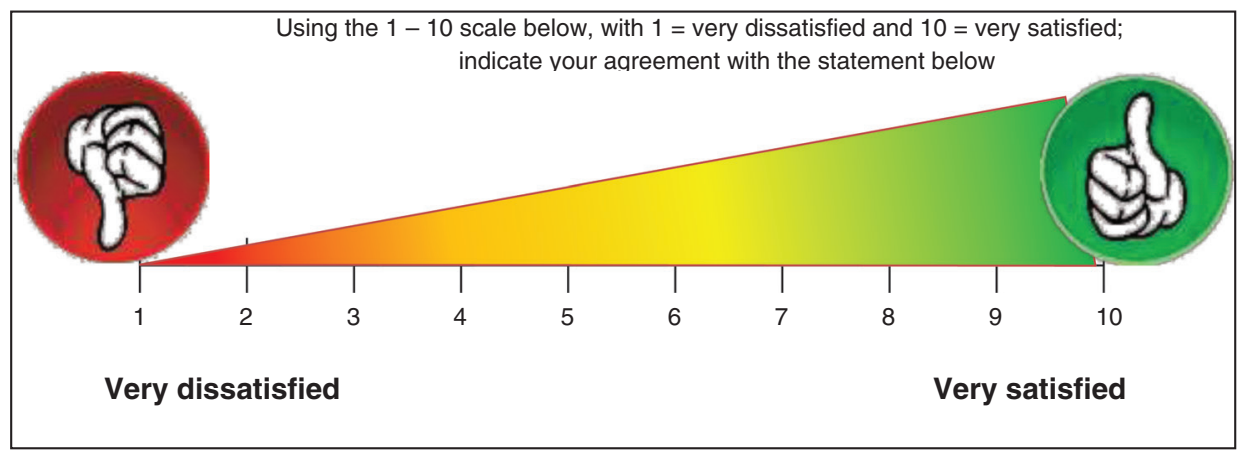

F7 What is the most important thing in your life?

First most important thing in my life is.

Second most important thing in my life

Third most important thing in my life

F8 What do you think are the three most serious problems in Thailand? Please rank from one to three.

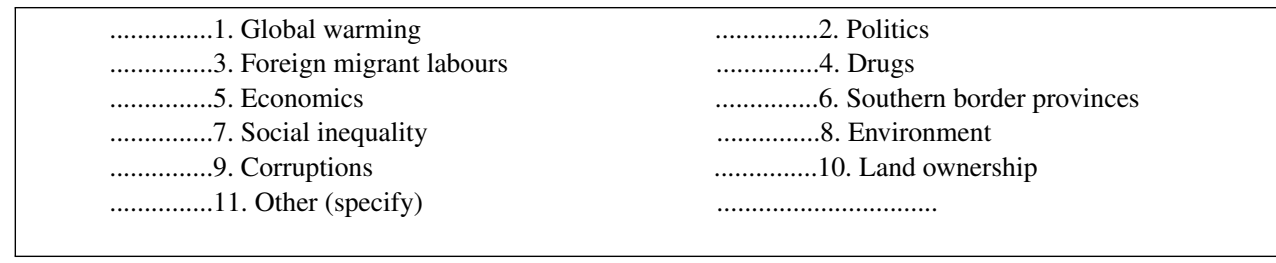




\section{Part G - Dwelling characteristics and living conditions}

\begin{tabular}{|c|c|c|c|}
\hline Item & Questions & Label & Skip to \\
\hline G1 & Wall or building material & $\begin{array}{l}\text { Brick, block, stone or cement...............1 } \\
\text { Wood .............. } \\
\text { Half brick, half wood.............. } 3 \\
\text { Makeshift, salvaged or improvised materials } \\
\text { from the local area; e.g., plant-based mate- } \\
\text { rial.............. } 4 \\
\text { Reused materials; e.g., cardboard, scrap. } 5 \\
\text { Other (specify)................6 } \\
\text { Unknown..............9 }\end{array}$ & \\
\hline $\mathrm{G} 2$ & $\begin{array}{l}\text { What is the general condition of } \\
\text { the area immediately around } \\
\text { the house with respect to } \\
\text { garbage disposal? }\end{array}$ & $\begin{array}{l}\text { Lots of uncollected garbage } \ldots \ldots \ldots \ldots \ldots . .1 \\
\text { Some uncollected garbage ................2 } \\
\text { Very little garbage................ } \\
\text { No garbage visible ...............4 } \\
\text { Not applicable............... }\end{array}$ & \\
\hline G3 & Garbage disposal area & $\begin{array}{l}\text { Presence of pests; e.g., cockroaches,rats. } 1 \\
\text { Bad odour.............. } 2 \\
\text { Clear separation of garbage............... } 3 \\
\text { Not applicable............... } 9\end{array}$ & \\
\hline G4 & $\begin{array}{l}\text { What kind of toilet facility do } \\
\text { members of your household } \\
\text { usually use? }\end{array}$ & $\begin{array}{l}\text { Flush toilet.............1 } \\
\text { Squat toilet..............2 } \\
\text { Flush toilet and squat toilet............. } 3 \\
\text { Pit latrine/Bucket toilet.............4 } \\
\text { No toilet facility..............5 }\end{array}$ & \\
\hline G5 & $\begin{array}{l}\text { Does your household have a } \\
\text { refrigerator? }\end{array}$ & $\begin{array}{l}\text { No................. } \\
\text { Yes............... }\end{array}$ & \\
\hline
\end{tabular}




\section{Appendix A.2: Data and methods}

Table A.1:

Indicators and cut-off points used in the main results and in sensitivity analyses

\begin{tabular}{|c|c|c|c|c|}
\hline & Health & Cognition & Out of poverty & Life satisfaction \\
\hline Main YoGL & $\begin{array}{l}\text { Can stand up from } \\
\text { a chair without } \\
\text { assistance }\end{array}$ & $\begin{array}{l}\text { Can read a full } \\
\text { sentence }\end{array}$ & $\begin{array}{l}\text { Does not skip } \\
\text { meals }\end{array}$ & $\begin{array}{l}\text { Reports life } \\
\text { satisfaction } \\
\text { score of five or } \\
\text { higher }\end{array}$ \\
\hline Sensitivity 1 & $\begin{array}{l}\text { Can stand up from } \\
\text { a chair with } \\
\text { assistance }\end{array}$ & $\begin{array}{l}\text { Can read a full } \\
\text { sentence }\end{array}$ & $\begin{array}{l}\text { Does not skip } \\
\text { meals }\end{array}$ & $\begin{array}{l}\text { Reports life } \\
\text { satisfaction } \\
\text { score of five or } \\
\text { higher }\end{array}$ \\
\hline Sensitivity 2 & $\begin{array}{l}\text { Can stand up from } \\
\text { a chair without } \\
\text { assistance }\end{array}$ & $\begin{array}{l}\text { Can read parts of a } \\
\text { sentence }\end{array}$ & $\begin{array}{l}\text { Does not skip } \\
\text { meals }\end{array}$ & $\begin{array}{l}\text { Reports life } \\
\text { satisfaction } \\
\text { score of five or } \\
\text { higher }\end{array}$ \\
\hline Sensitivity 3 & $\begin{array}{l}\text { Can stand up from } \\
\text { a chair without } \\
\text { assistance }\end{array}$ & $\begin{array}{l}\text { Can read a full } \\
\text { sentence }\end{array}$ & $\begin{array}{l}\text { Does not skip } \\
\text { meals }\end{array}$ & $\begin{array}{l}\text { Reports life } \\
\text { satisfaction } \\
\text { score of four or } \\
\text { higher }\end{array}$ \\
\hline Sensitivity 4 & $\begin{array}{l}\text { Can stand up from } \\
\text { a chair without } \\
\text { assistance }\end{array}$ & $\begin{array}{l}\text { Can read a full } \\
\text { sentence }\end{array}$ & $\begin{array}{l}\text { Does not skip } \\
\text { meals }\end{array}$ & $\begin{array}{l}\text { Reports life } \\
\text { satisfaction } \\
\text { score of six or } \\
\text { higher }\end{array}$ \\
\hline Sensitivity 5 & $\begin{array}{l}\text { Positive scores on } \\
\text { all five-item } \\
\text { ADLs }\end{array}$ & $\begin{array}{l}\text { Can read a full } \\
\text { sentence }\end{array}$ & $\begin{array}{l}\text { Does not skip } \\
\text { meals }\end{array}$ & $\begin{array}{l}\text { Reports life } \\
\text { satisfaction } \\
\text { score of five or } \\
\text { higher }\end{array}$ \\
\hline Sensitivity 6 & $\begin{array}{l}\text { Positive scores on } \\
\text { all 12-item } \\
\text { ADLs }\end{array}$ & $\begin{array}{l}\text { Can read a full } \\
\text { sentence }\end{array}$ & $\begin{array}{l}\text { Does not skip } \\
\text { meals }\end{array}$ & $\begin{array}{l}\text { Reports life } \\
\text { satisfaction } \\
\text { score of five or } \\
\text { higher }\end{array}$ \\
\hline Sensitivity 7 & $\begin{array}{l}\text { GALI: does not } \\
\text { report severe } \\
\text { limitation }\end{array}$ & $\begin{array}{l}\text { Can read a full } \\
\text { sentence }\end{array}$ & $\begin{array}{l}\text { Does not skip } \\
\text { meals }\end{array}$ & $\begin{array}{l}\text { Reports life } \\
\text { satisfaction } \\
\text { score of five or } \\
\text { higher }\end{array}$ \\
\hline Sensitivity 8 & $\begin{array}{l}\text { Can stand up from } \\
\text { a chair without } \\
\text { assistance }\end{array}$ & $\begin{array}{l}\text { Reports being able } \\
\text { to read without } \\
\text { difficulty }\end{array}$ & $\begin{array}{l}\text { Does not skip } \\
\text { meals }\end{array}$ & $\begin{array}{l}\text { Reports life } \\
\text { satisfaction } \\
\text { score of five or } \\
\text { higher }\end{array}$ \\
\hline Sensitivity 9 & $\begin{array}{l}\text { Can stand up from } \\
\text { a chair without } \\
\text { assistance }\end{array}$ & $\begin{array}{l}\text { Reports being able } \\
\text { to write without } \\
\text { difficulty }\end{array}$ & $\begin{array}{l}\text { Does not skip } \\
\text { meals }\end{array}$ & $\begin{array}{l}\text { Reports life } \\
\text { satisfaction } \\
\text { score of five or } \\
\text { higher }\end{array}$ \\
\hline Sensitivity 10 & $\begin{array}{l}\text { Can stand up from } \\
\text { a chair without } \\
\text { assistance }\end{array}$ & $\begin{array}{l}\text { Able to answer } \\
\text { correctly all } \\
\text { reading with } \\
\text { understanding } \\
\text { questions }\end{array}$ & $\begin{array}{l}\text { Does not skip } \\
\text { meals }\end{array}$ & $\begin{array}{l}\text { Reports life } \\
\text { satisfaction } \\
\text { score of five or } \\
\text { higher }\end{array}$ \\
\hline
\end{tabular}

Continued 
Table A.1:

Continued

\begin{tabular}{|c|c|c|c|c|}
\hline & Health & Cognition & Out of poverty & Life satisfaction \\
\hline Sensitivity 11 & $\begin{array}{c}\text { Can stand up from } \\
\text { a chair without } \\
\text { assistance }\end{array}$ & $\begin{array}{l}\text { Can read a full } \\
\text { sentence }\end{array}$ & $\begin{array}{l}\text { Does not limit } \\
\text { variety of foods } \\
\text { due to a lack of } \\
\text { resources }\end{array}$ & $\begin{array}{l}\text { Reports life } \\
\text { satisfaction } \\
\text { score of five or } \\
\text { higher }\end{array}$ \\
\hline Sensitivity 12 & $\begin{array}{c}\text { Can stand up from } \\
\text { a chair without } \\
\text { assistance }\end{array}$ & $\begin{array}{l}\text { Can read a full } \\
\text { sentence }\end{array}$ & $\begin{array}{c}\text { Does not own a } \\
\text { welfare card }\end{array}$ & $\begin{array}{l}\text { Reports life } \\
\text { satisfaction } \\
\text { score of five or } \\
\text { higher }\end{array}$ \\
\hline Sensitivity 13 & $\begin{array}{c}\text { Can stand up from } \\
\text { a chair without } \\
\text { assistance }\end{array}$ & $\begin{array}{l}\text { Can read a full } \\
\text { sentence }\end{array}$ & $\begin{array}{l}\text { Flush toilet } \\
\text { available in the } \\
\text { house }\end{array}$ & $\begin{array}{l}\text { Reports life } \\
\text { satisfaction } \\
\text { score of five or } \\
\text { higher }\end{array}$ \\
\hline Sensitivity 14 & $\begin{array}{c}\text { Can stand up from } \\
\text { a chair without } \\
\text { assistance }\end{array}$ & $\begin{array}{l}\text { Can read a full } \\
\text { sentence }\end{array}$ & $\begin{array}{l}\text { Does not skip } \\
\text { meals }\end{array}$ & $\begin{array}{l}\text { Life close to ideal } \\
\text { (reports score of } \\
\text { three or higher) }\end{array}$ \\
\hline Sensitivity 15 & $\begin{array}{c}\text { Can stand up from } \\
\text { a chair without } \\
\text { assistance }\end{array}$ & $\begin{array}{l}\text { Can read a full } \\
\text { sentence }\end{array}$ & $\begin{array}{l}\text { Does not skip } \\
\text { meals }\end{array}$ & $\begin{array}{l}\text { Satisfied with life } \\
\text { (reports score of } \\
\text { three or higher) }\end{array}$ \\
\hline Sensitivity 16 & $\begin{array}{c}\text { Can stand up from } \\
\text { a chair without } \\
\text { assistance }\end{array}$ & $\begin{array}{l}\text { Can read a full } \\
\text { sentence }\end{array}$ & $\begin{array}{l}\text { Does not skip } \\
\text { meals }\end{array}$ & $\begin{array}{l}\text { Would change } \\
\text { almost nothing } \\
\text { in life (reports } \\
\text { score of three or } \\
\text { higher) }\end{array}$ \\
\hline
\end{tabular}

Note: Indicators that are different from the main specification are marked in grey. 
Table A.2:

Share of respondents by age and sex who meet all YoGL conditions, and who have positive scores in individual dimensions

\begin{tabular}{|c|c|c|c|c|c|c|}
\hline Sex & Age group & YoGL & Healthy & Cognitively able & Satisfied & Out of poverty \\
\hline Female & 20 & 0.76 & 1 & 0.76 & 1 & 0.9 \\
\hline Female & 25 & 0.73 & 1 & 0.87 & 0.93 & 0.83 \\
\hline Female & 30 & 0.72 & 1 & 0.84 & 0.94 & 0.91 \\
\hline Female & 35 & 0.53 & 1 & 0.74 & 0.95 & 0.77 \\
\hline Female & 40 & 0.56 & 1 & 0.67 & 1 & 0.85 \\
\hline Female & 45 & 0.42 & 1 & 0.52 & 0.96 & 0.81 \\
\hline Female & 50 & 0.36 & 0.98 & 0.43 & 0.92 & 0.81 \\
\hline Female & 55 & 0.31 & 0.97 & 0.39 & 0.94 & 0.81 \\
\hline Female & 60 & 0.29 & 0.97 & 0.31 & 0.98 & 0.91 \\
\hline Female & 65 & 0.14 & 0.95 & 0.17 & 0.9 & 0.8 \\
\hline Female & 70 & 0.18 & 0.82 & 0.21 & 0.94 & 0.82 \\
\hline Female & 75 & 0.24 & 0.83 & 0.29 & 0.95 & 0.93 \\
\hline Female & 85 & 0.24 & 0.83 & 0.29 & 0.95 & 0.93 \\
\hline Female & 80 & 0.24 & 0.83 & 0.29 & 0.95 & 0.93 \\
\hline Male & 20 & 0.6 & 1 & 0.7 & 1 & 0.9 \\
\hline Male & 25 & 0.91 & 0.91 & 0.91 & 1 & 1 \\
\hline Male & 30 & 0.67 & 1 & 0.67 & 1 & 0.83 \\
\hline Male & 35 & 0.79 & 0.93 & 0.93 & 1 & 0.79 \\
\hline Male & 40 & 0.67 & 1 & 0.79 & 1 & 0.83 \\
\hline Male & 45 & 0.31 & 1 & 0.47 & 0.87 & 0.73 \\
\hline Male & 50 & 0.5 & 0.91 & 0.71 & 0.94 & 0.79 \\
\hline Male & 55 & 0.5 & 0.98 & 0.57 & 0.93 & 0.91 \\
\hline Male & 60 & 0.33 & 1 & 0.43 & 0.92 & 0.82 \\
\hline Male & 65 & 0.42 & 1 & 0.45 & 1 & 0.81 \\
\hline Male & 70 & 0.52 & 1 & 0.57 & 0.96 & 0.87 \\
\hline Male & 75 & 0.19 & 0.9 & 0.24 & 1 & 0.71 \\
\hline Male & 85 & 0.19 & 0.9 & 0.24 & 1 & 0.71 \\
\hline Male & 80 & 0.19 & 0.9 & 0.24 & 1 & 0.71 \\
\hline
\end{tabular}

Open Access This article is published under the terms of the Creative Commons Attribution 4.0 International License (https://creativecommons.org/licenses/by/4.0/) that allows the sharing, use and adaptation in any medium, provided that the user gives appropriate credit, provides a link to the license, and indicates if changes were made. 